Article

\title{
Immune Status and Hepatic Antioxidant Capacity of Gilthead Seabream Sparus aurata Juveniles Fed Yeast and Microalga Derived $\beta$-glucans
}

\author{
Bruno Reis 1,2,3,4,*, Ana Teresa Gonçalves 1,5, Paulo Santos 2,3 $\mathbb{D}$, Manuel Sardinha 1,t, Luís E. C. Conceição ${ }^{1} \mathbb{D}$, \\ Renata Serradeiro ${ }^{6}$, Jaume Pérez-Sánchez ${ }^{7}$, Josep Calduch-Giner ${ }^{7}$, Ulrike Schmid-Staiger ${ }^{8}$, Konstantin Frick ${ }^{9}$, \\ Jorge Dias ${ }^{1}$ ad and Benjamín Costas $2,3, *$ (D)
}

Citation: Reis, B.; Gonçalves, A.T.; Santos, P.; Sardinha, M.; Conceição, L.E.C.; Serradeiro, R.; Pérez-Sánchez, J.; Calduch-Giner, J.; Schmid-Staiger, U.; Frick, K.; et al. Immune Status and Hepatic Antioxidant Capacity of Gilthead Seabream Sparus aurata Juveniles Fed Yeast and Microalga Derived $\beta$-glucans. Mar. Drugs 2021, 19, 653. https://doi.org/10.3390/ md19120653

Academic Editor: Carlos Almeida

Received: 25 October 2021

Accepted: 17 November 2021

Published: 23 November 2021

Publisher's Note: MDPI stays neutral with regard to jurisdictional claims in published maps and institutional affiliations.

Copyright: (c) 2021 by the authors. Licensee MDPI, Basel, Switzerland. This article is an open access article distributed under the terms and conditions of the Creative Commons Attribution (CC BY) license (https:/ / creativecommons.org/licenses/by/ $4.0 /)$.
1 SPAROS Lda., Área Empresarial de Marim, Lote C, 8700-221 Olhão, Portugal; AnaGoncalves@sparos.pt (A.T.G.); manuelsardinha@sparos.pt (M.S.); LuisConceicao@sparos.pt (L.E.C.C.); jorgedias@sparos.pt (J.D.)

2 Centro Interdisciplinar de Investigação Marinha e Ambiental (CIIMAR), Universidade do Porto, Terminal de Cruzeiros de Leixões, Av. General Norton de Matos s/n, 4450-208 Matosinhos, Portugal; paulo.santos@ciimar.up.pt

3 Instituto de Ciências Biomédicas Abel Salazar (ICBAS-UP), Universidade do Porto, R. Jorge de Viterbo Ferreira 228, 4050-313 Porto, Portugal

4 Sorgal S.A., Estrada Nacional 109, Lugar da Pardala, 3880-728 São João de Ovar, Portugal

5 GreenCoLab_Associação Oceano Verde, Campus de Gambelas, Universidade do Algarve, 8005-139 Faro, Portugal

6 Riasearch, Rua do Farol, 131, Torrão do Lameiro, 3880-394 Ovar, Portugal; renataserradeiro@riasearch.pt

7 Nutrigenomics and Fish Growth Endocrinology Group, Institute of Aquaculture Torre de la Sal, IATS-CSIC, 12595 Castellón, Spain; jaime.perez.sanchez@csic.es (J.P.-S.); calduch@iats.csic.es (J.C.-G.)

8 Fraunhofer Institute for Interfacial Engineering and Biotechnology IGB, Innovation Field Algae Biotechnology—Development, Nobelstrasse 12, 70569 Stuttgart, Germany; ulrike.schmid-staiger@igb.fraunhofer.de

9 Institute of Interfacial Process Engineering and Plasma Technology, University of Stuttgart, Pfaffenwaldring 31, 70569 Stuttgart, Germany; konstantin.frick@igb.fraunhofer.de

* Correspondence: breis@ciimar.up.pt (B.R.); bcostas@ciimar.up.pt (B.C.); Tel.: +351-223-401-840 (B.R.); +351-223-401-838 (B.C.)

+ Current affiliation: Biomar AS, Global RD Department, Havnegata 9, 7010 Trondheim, Norway.

Abstract: This work aimed to evaluate the effects of dietary supplementation with $\beta$-glucans extracted from yeast (Saccharomyces cerevisiae) and microalga (Phaeodactylum tricornutum) on gene expression, oxidative stress biomarkers and plasma immune parameters in gilthead seabream (Sparus aurata) juveniles. A practical commercial diet was used as the control (CTRL), and three others based on CTRL were further supplemented with different $\beta$-glucan extracts. One was derived from $S$. cerevisiae (diet MG) and two different extracts of $21 \%$ and $37 \%$ P. tricornutum-derived $\beta$-glucans (defined as Phaeo21 and Phaeo37), to give a final $0.06 \% \beta$-glucan dietary concentration. Quadruplicate groups of 95 gilthead seabream (initial body weight: $4.1 \pm 0.1 \mathrm{~g}$ ) were fed to satiation three times a day for 8 weeks in a pulse-feeding regimen, with experimental diets intercalated with the CTRL dietary treatment every 2 weeks. After 8 weeks of feeding, all groups showed equal growth performance and no changes were found in plasma innate immune status. Nonetheless, fish groups fed $\beta$-glucans supplemented diets showed an improved anti-oxidant status compared to those fed CTRL at both sampling points (i.e., 2 and 8 weeks). The intestinal gene expression analysis highlighted the immunomodulatory role of Phaeo37 diet after 8 weeks, inducing an immune tolerance effect in gilthead seabream intestine, and a general down-regulation of immune-related gene expression. In conclusion, the results suggest that the dietary pulse administration of a P. tricornutum $37 \%$ enriched- $\beta$-glucans extract might be used as a counter-measure in a context of gut inflammation, due to its immune-tolerant and anti-oxidative effects.

Keywords: Saccharomyces cerevisiae; Phaeodactylum tricornutum; Sparus aurata; $\beta$-glucans; pulse feeding; immune tolerance 


\section{Introduction}

Aquaculture is the fastest growing food-sector related industry, and as practices become more intensive, the risk of disease outbreaks increases accordingly [1,2]. In fact, animal health-related issues are nowadays the major constraint for aquaculture expansion and sustainability [3]. To date, one of the main strategies to cope with disease outbreaks in aquaculture has been the use of antibiotics. Although this issue has been mitigated in recent years with more restrictive legislation and regulations, antibiotics are still routinely used, leading to the emergence of new antibiotic-resistant bacteria [1]. In addition to vaccination, an alternative strategy to the use of antibiotics is the adoption of prophylactic measures through nutrition, such as the incorporation of immunostimulants and prebiotics in feeds to enhance fish disease resistance and general health $[2,4,5]$.

Marine microalgae are a rich source of bioactive compounds [6] that are drawing increasing attention considering their use in different applications including functional feeds $[7,8]$. Phaeodactylum tricornutum is a marine diatom, unicellular brown microalgae rich in several health beneficial compounds such as $\beta$-glucans (BGs) [9-11]. BGs can be naturally found as cell wall components in bacteria, yeast, fungi, plants, micro- and macroalgae, and due to their promising biological activities, BGs have been extensively studied in vertebrates [2,12-14]. These polysaccharides can act as a prebiotic, enhancing the growth of commensal microbiota and by directly stimulating the innate immune system through interaction with specific cell receptors [4]. BGs bioactivity depends on their degree of branching, size and molecular structure [15]. However, those with higher biological activity show a common pattern: a repeating chain of (1-3)-linked $\beta$-D-glucopyranosyl units with randomly branched single $\beta$-D -glucopyranosyl units attached by $1-6$ or $1-4$ linkages $[2,15]$. These repeating patterns, a feature shared with bacterial lipopolysaccharides (LPS), can be recognized by the host's cell pattern recognition receptors (PRR) and are termed pathogenassociated microbial patterns (PAMPs). Upon recognition. they can elicit an inflammatory response and activate the host's innate immune cells [12].

In mammals, dectin- 1 is the best described BGs receptor, considered to be the most important for recognition and signal transduction. It is a C-type lectin receptor (CLR) which is predominantly expressed on cells from both the monocyte/macrophage and neutrophil lineages [12,16]. In a former study, European common carp (Cyprinius carpio) macrophages were activated with curdlan, a dectin-1-specific BG ligand in mammals, showing that immune modulatory effects in carp macrophages could be triggered by a member of the CLR family, although different from dectin-1 receptor [17]. In teleosts, the specific receptors involved in the recognition of BGs and consequent downstream signalling remain to be elucidated [14,18-20]. In contrast, the beneficial effects of BGs in fish innate immune response are well documented. Most of the studies focusing on fish showed that oral administration of BGs not only benefits innate immune response, such as the increase of phagocytic capacity, oxidative burst, lysozyme and complement activity [21-24], but also modulates immune gene expression in different organs [25-27]. However, the use of BG-rich microalgae cell extracts as feed supplements to modulate both the systemic and local immune response is still poorly explored. Therefore, the present study aimed to evaluate the effects of $\beta$-glucans extracted from microalga (P. tricornutum) and yeast (Saccharomyces cerevisiae), when applied as dietary supplements for juveniles of a valuable fish species for European aquaculture such as gilthead seabream (Sparus aurata).

\section{Results}

\subsection{Growth Performance}

Growth performance data are presented in Table 1. At the end of the trial (8 weeks), all fish showed similar final whole-body weight, regardless of dietary treatment. All groups showed similar feed conversion ratio (FCR) and relative growth rate (RGR) values (1.2 and $3.8 \%$ day $^{-1}$, respectively). 
Table 1. Growth performance parameters in gilthead seabream juveniles after 8 weeks of feeding regimen. Data are the mean $\pm \operatorname{SEM}(n=4)$.

\begin{tabular}{ccccc}
\hline \multicolumn{5}{c}{ 8 Weeks } \\
\hline DIETS & CTRL & MG & Phaeo21 & Phaeo37 \\
\hline IBW & $4.18 \pm 0.04$ & $4.12 \pm 0.02$ & $4.12 \pm 0.05$ & $4.15 \pm 0.05$ \\
FBW & $41.36 \pm 0.81$ & $42.48 \pm 0.43$ & $42.08 \pm 0.53$ & $41.93 \pm 0.97$ \\
RGR & $3.77 \pm 0.03$ & $3.83 \pm 0.02$ & $3.82 \pm 0.03$ & $3.8 \pm 0.03$ \\
FCR & $1.20 \pm 0.01$ & $1.19 \pm 0.01$ & $1.21 \pm 0.02$ & $1.19 \pm 0.04$ \\
\hline \hline
\end{tabular}

IBW: initial body weight (g); FBW: final body weight (g); RGR: relative growth rate (\% average body weight/day) and FCR: feed conversion ratio.

\subsection{Haematological Profile and Humoral Parameters}

Peripheral cell dynamics were analysed at both sampling points (Table 2). The relative percentage of circulating lymphocytes increased in fish-fed Phaeo21 compared to CTRL and Phaeo37 groups after 2 weeks of feeding. In contrast, the same cell type showed decreased percentages in fish fed MG and Phaeo21 dietary treatments compared to those fed CTRL in the second (8 weeks) sampling. Furthermore, after 8 weeks, peripheral thrombocytes were higher in MG and Phaeo37 compared to CTRL. Monocytes and neutrophils numbers remained unaltered among dietary groups at both sampling points. Plasma humoral parameters (i.e., bactericidal activity, antiprotease activity and IgM) remained unchanged among dietary treatments at both 2 and 8 weeks (Table 3 ).

Table 2. Percentage values of peripheral blood leucocytes (thrombocytes, lymphocytes, monocytes and neutrophils) in gilthead seabream juveniles after 2 and 8 weeks of feeding regimen. Data are the mean $\pm \operatorname{SEM}(n=12)$.

\begin{tabular}{|c|c|c|c|c|c|c|c|c|}
\hline \multirow[b]{2}{*}{ DIETS } & \multicolumn{4}{|c|}{2 Weeks } & \multicolumn{4}{|c|}{8 Weeks } \\
\hline & CTRL & MG & Phaeo21 & Phaeo37 & CTRL & MG & Phaeo21 & Phaeo37 \\
\hline CELLS (\%) & & & & & & & & \\
\hline Thrombocytes & $65.2 \pm 2.0$ & $63.0 \pm 2.2$ & $60.3 \pm 1.8$ & $64.7 \pm 1.6$ & $71.2^{b} \pm 2.6$ & $78.5^{\mathrm{a}} \pm 1.4$ & $76.4^{\mathrm{a}, \mathrm{b}} \pm 2.5$ & $81.0^{\mathrm{a}} \pm 0.8$ \\
\hline Lymphocytes & $24.1^{\mathrm{b}} \pm 1.5$ & $28.3^{\mathrm{a}, \mathrm{b}} \pm 1.9$ & $30.7^{\mathrm{a}} \pm 1.4$ & $24.8^{b} \pm 1.3$ & $18.4^{\mathrm{a}} \pm 2.5$ & $13.0^{\mathrm{b}} \pm 1.0$ & $13.1^{\mathrm{b}} \pm 2.6$ & $13.4^{\mathrm{a}, \mathrm{b}} \pm 0.8$ \\
\hline Monocytes & $5.3 \pm 0.8$ & $3.5 \pm 0.7$ & $4.4 \pm 0.7$ & $5.2 \pm 0.4$ & $3.4 \pm 0.6$ & $2.4 \pm 0.7$ & $3.1 \pm 0.6$ & $2.0 \pm 0.5$ \\
\hline Neutrophils & $4.4 \pm 1.0$ & $4.1 \pm 0.9$ & $4.1 \pm 0.7$ & $4.8 \pm 0.7$ & $4.7 \pm 0.4$ & $5.6 \pm 0.6$ & $4.3 \pm 0.7$ & $3.6 \pm 0.6$ \\
\hline
\end{tabular}

Different superscript letters indicate significant differences between diets $(p<0.05)$ within the same sampling point.

Table 3. Plasma immune parameters of gilthead seabream juveniles after 2 and 8 weeks feeding (antiprotease activity, bactericidal activity and immunoglobulin $M)$. Data are the mean $\pm \operatorname{SEM}(n=12)$. Different letters indicate significant differences between dietary treatments $(p<0.05)$.

\begin{tabular}{|c|c|c|c|c|c|c|c|c|}
\hline \multirow[b]{2}{*}{ DIETS } & \multicolumn{4}{|c|}{2 Weeks } & \multicolumn{4}{|c|}{8 Weeks } \\
\hline & CTRL & MG & Phaeo21 & Phaeo37 & CTRL & MG & Phaeo21 & Phaeo37 \\
\hline Antiprotease act (\%) & $95.7 \pm 0.6$ & $96.0 \pm 0.5$ & $95.5 \pm 0.7$ & $95.4 \pm 0.6$ & $97.9 \pm 0.2$ & $98.1 \pm 0.1$ & $97.9 \pm 0.2$ & $98.2 \pm 0.2$ \\
\hline Bactericidal act (\%) & $45.0 \pm 6.3$ & $35.5 \pm 4.0$ & $40.3 \pm 6.6$ & $45.4 \pm 4.4$ & $53.3 \pm 7.2$ & $56.5 \pm 5.8$ & $57.4 \pm 6.8$ & $61.8 \pm 4.8$ \\
\hline $\operatorname{IgM}(\mathrm{OD} 450 \mathrm{~nm})$ & $0.31 \pm 0.03$ & $0.32 \pm 0.03$ & $0.37 \pm 0.05$ & $0.29 \pm 0.03$ & $0.62 \pm 0.05$ & $0.53 \pm 0.03$ & $0.47 \pm 0.05$ & $0.55 \pm 0.03$ \\
\hline
\end{tabular}

\subsection{Oxidative Stress Biomarkers}

Hepatic oxidative stress biomarkers showed significant differences at both sampling points (Figure 1). Lipid peroxidation decreased in seabream-fed MG and Phaeo37 diets compared to those fed CTRL at 2 weeks (early sampling), while the extent of lipid peroxidation was similar among groups after 8 weeks (final sampling). Catalase (CAT) and superoxide dismutase (SOD) activities were not affected by the dietary treatments at 2 weeks, however, CAT activity increased in Phaeo21 compared to Phaeo37 group at 8 weeks. SOD activity was enhanced in Phaeo37-fed fish compared to those fed CTRL and MG1000 dietary treatments. Total glutathione remained unaltered among dietary groups at both sampling points. 
LPO
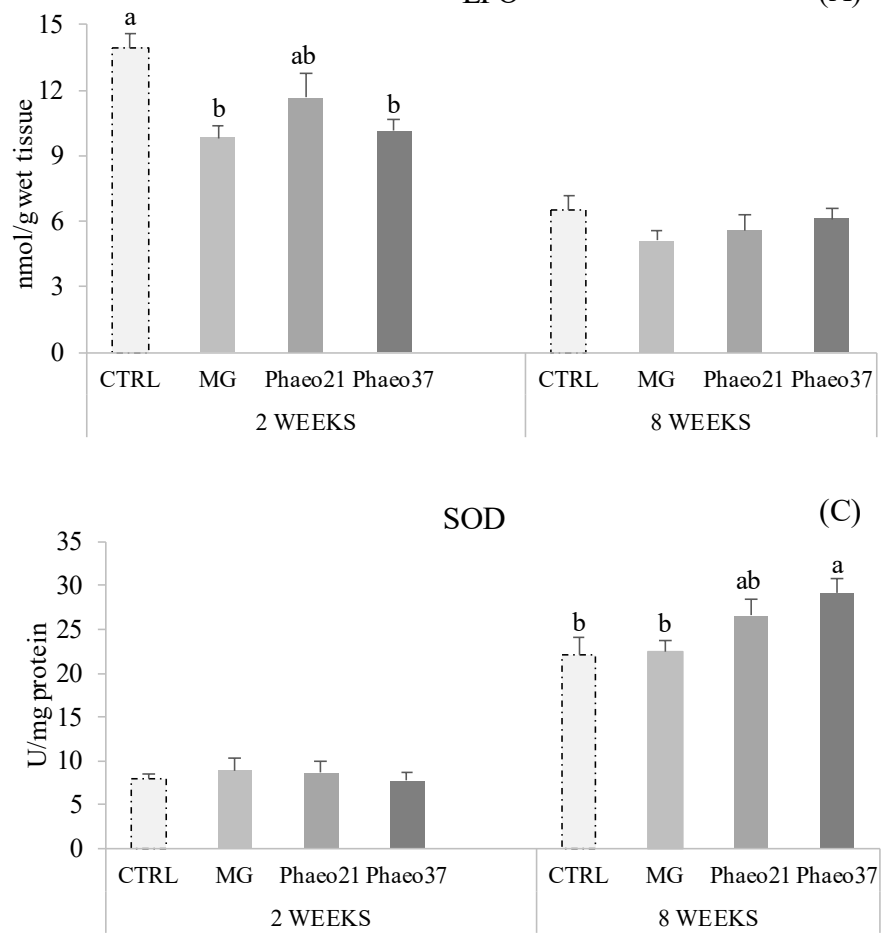

A)
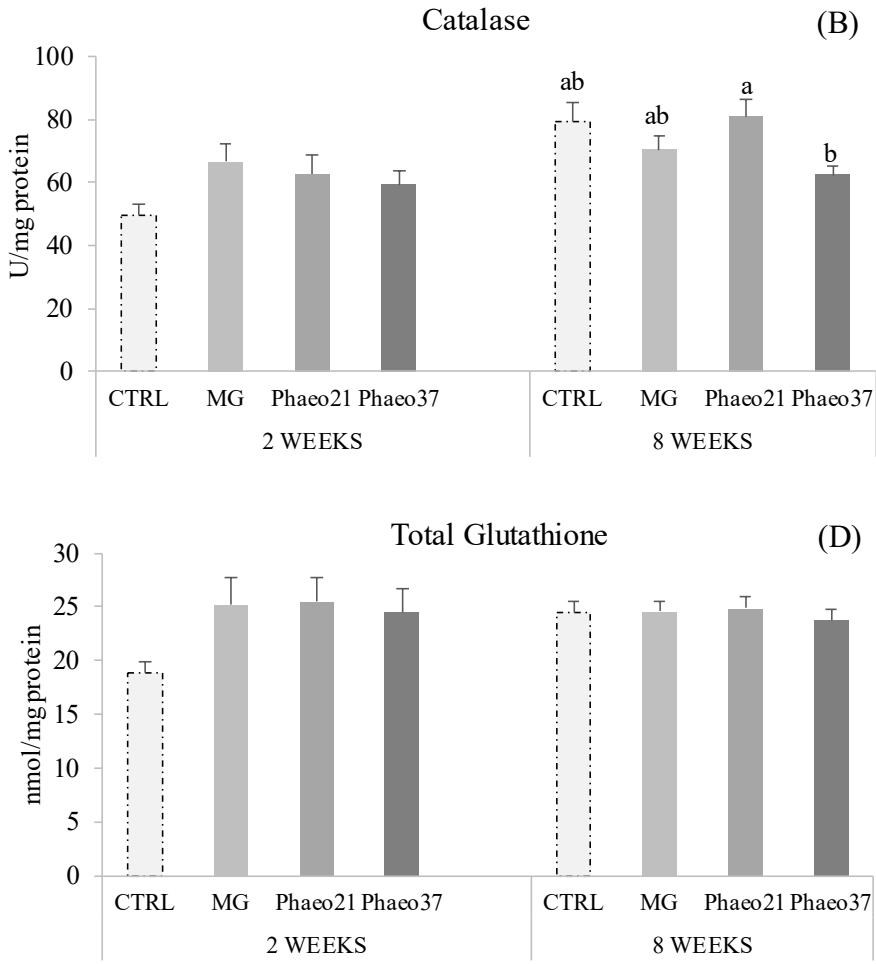

Figure 1. Liver oxidative stress biomarkers of gilthead seabream juveniles after 2 and 8 weeks feeding. Lipid peroxidation (LPO) (A); Catalase activity (CAT) (B); Superoxide dismutase activity (SOD) (C) and Total Glutathione (D). Data are the mean $\pm \operatorname{SEM}(n=12)$. Different lowercase letters indicate significant differences between dietary treatments $(p<0.05)$.

\subsection{Multivariate Analysis from Physiological Parameters}

An overall multivariate analysis combining raw data from haematological, humoral and hepatic oxidative stress biomarkers (using PCA-DA) was performed to discriminate the physiological effects caused by the experimental diets both at 2 and 8 weeks of feeding (Figure 2). The first two discriminant functions accounted for $95 \%$ of dataset variability at 2 weeks. Group discrimination was significant (Wilk's lambda $=0.3, p=0.01$ ) highlighting the differences between CTRL and BG groups $(p<0.03)$. This discrimination was loaded by lower lipid peroxidation, higher CAT and tGSH and to a lesser extent higher antiproteases activity in BG groups. At 8 weeks, groups were discriminated (Wilk's lambda $=0.2$; $p<0.001$ ) and the first two discriminant factors accounted for $84 \%$ of dataset variability. CTRL and MG dietary treatments were significantly discriminated from the Phaeo groups $(p<0.04)$ and this separation was loaded by a higher SOD activity and thrombocyte percentage in the last groups. 

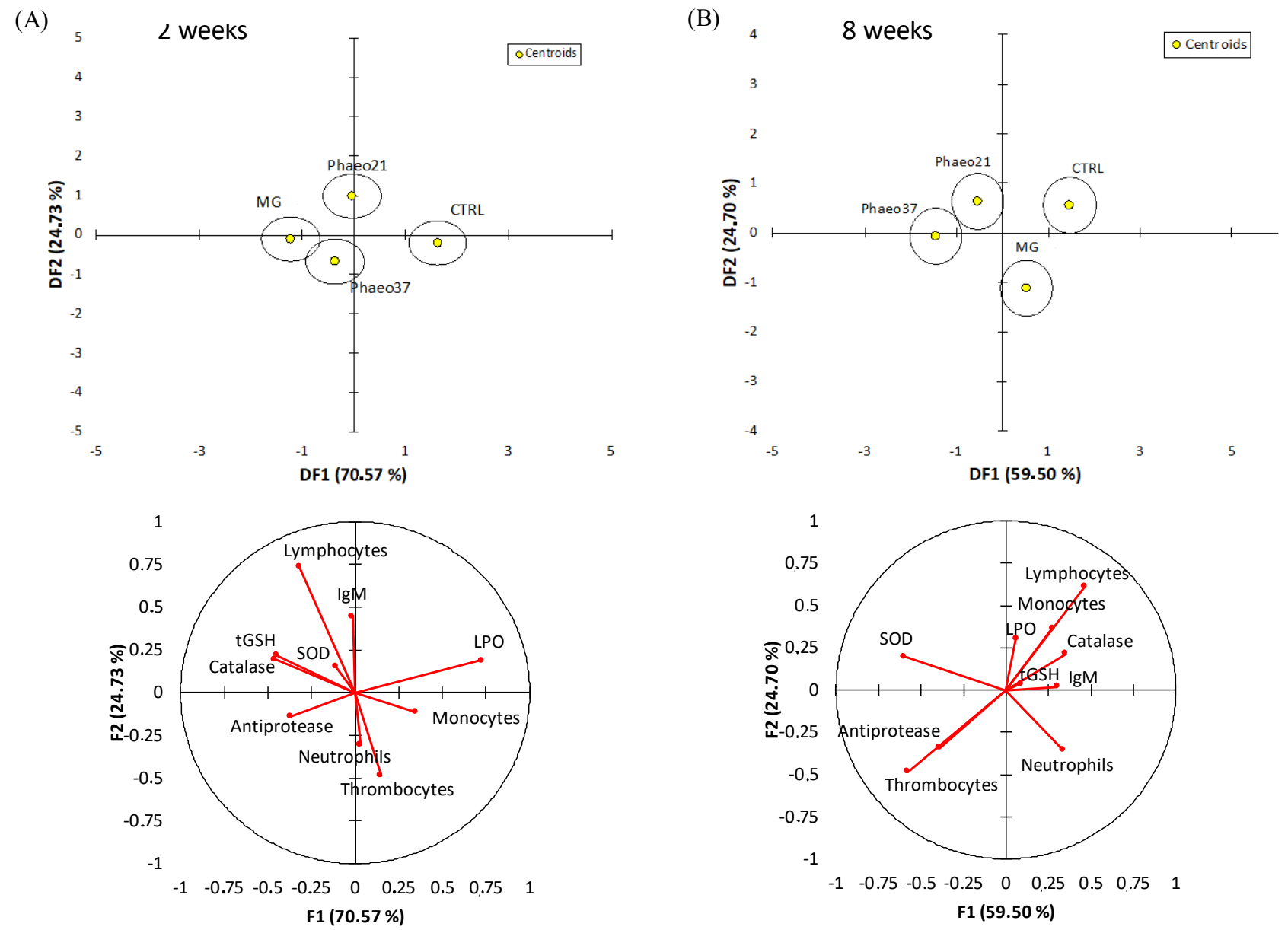

Figure 2. Discriminant analysis of experimental groups based on all physiological biomarkers analysed in the target tissues (yellow marker indicates the centroids of each group) and variables loads for DF1 and DF2 at 2 and 8 weeks. (A) 2 weeks; (B) 8 weeks.

\subsection{Gene Expression Analysis}

Different pathways represented in this gene array showed significant dietary effects in the proximal intestine. Proliferating cell nuclear antigen gene ( $p c n a)$ was down-regulated in Phaeo37-fed fish at 2 weeks (Figure 3A). In contrast, different genes belonging to different molecular and cellular pathways were down-regulated in seabream-fed Phaeo37 after 8 weeks of feeding, in particular, fucolectin ( $f c l$ (Figure 3D), as well as gap junction cx32.2 protein (cx32.2) (Figure 3B) genes. Moreover, the latter gene was down-regulated in fish fed MG as well as interleukin 10 (il10) (Figure 3C). Complete relative gene expression profile of the anterior intestine is provided as Supplementary Material (Tables S1 and S2). According to the Supplementary Tables, it was found that the mRNA expression levels of the other analysed genes showed no statistically significant differences among experimental groups. 


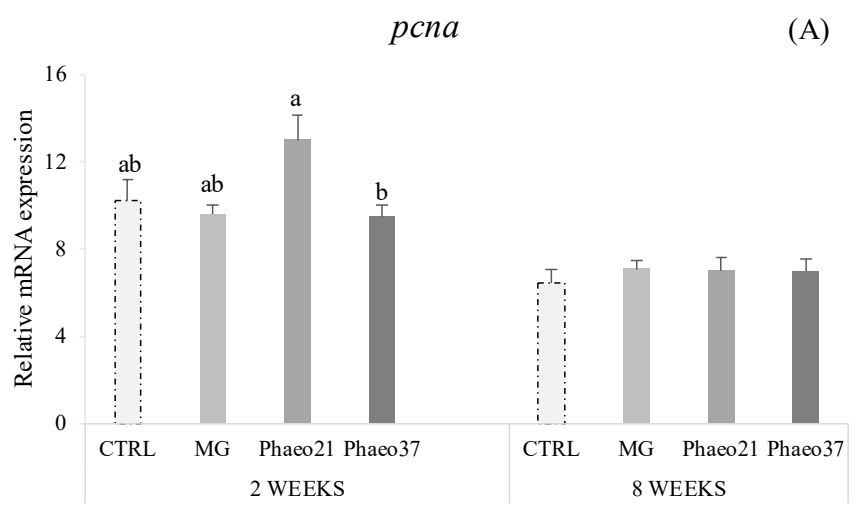

illo

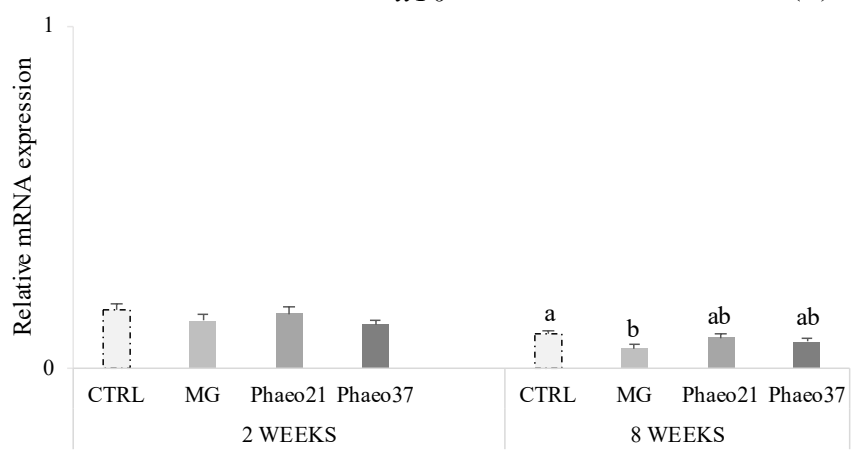

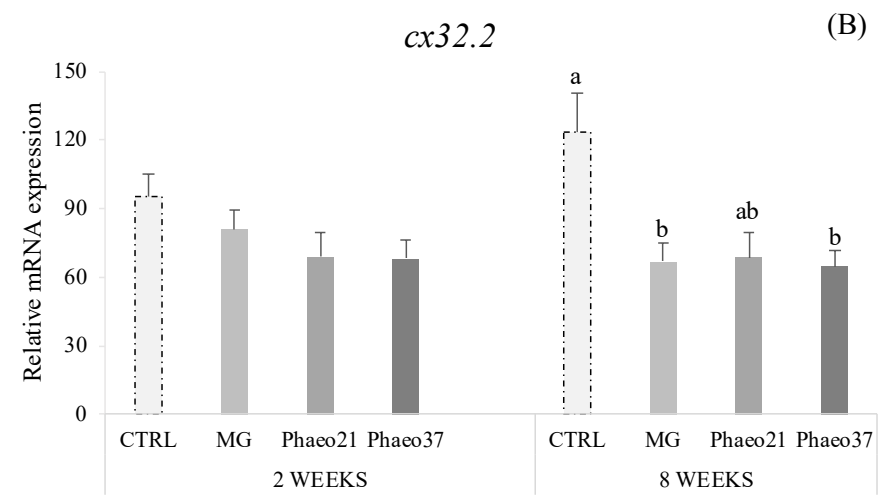

$f c l$

(D)

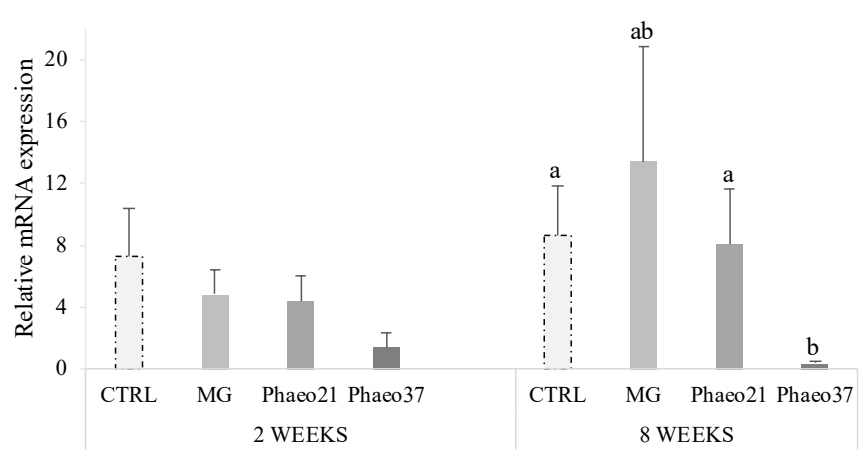

Figure 3. Relative mRNA expression of pcna (A), cx32.2 (B), il10 (C) and $f c l(\mathbf{D})$ genes in the anterior intestinal tissue of gilthead seabream juveniles fed the experimental diets for 2 and 8 weeks. Data are the mean $\pm \operatorname{SEM}(n=9)$. All data values for each gene were in reference to the expression level of $c l d n 12$ of CTRL fish with an arbitrary assigned value of $1 . p$ values result from one-way ANOVA. Different lowercase letters indicate significant differences among dietary treatments $(p<0.05)$.

Further differences between fish fed the experimental diets in comparison to CTRL were highlighted by a clustering heatmap of gene expression after 8 weeks of feeding (Figure 4). This approach pointed to Phaeo37 as the experimental diet more apart from CTRL in the gene expression pattern. In order to get a clearer picture of the dietary effect on intestinal gene expression, an overall multivariate analysis combining raw data from the different genes (using PLS-DA) in CTRL and Phaeo 37 groups was performed. For the 2 weeks feeding period, the model was not able to show a clear separation between experimental groups (data not shown). However, at 8 weeks, the same approach showed that expression patterns can be summarized through two main components that explain $88.11 \%$ of total variance (Figure $5 \mathrm{~A})$. On the one hand, component $1(63.59 \%$ of total variance, $\mathrm{X}$-axis) appeared to be mostly related to diet effect, as it was able to clearly separate Phaeo37- and CTRL-fed fish. On the other hand, component 2 (19.52\% of total variance, Y-axis) appeared to account for inner group variability. A total of 20 genes showed a VIP value $>1$, highlighting their contribution to diet differences (Figure 5B). 


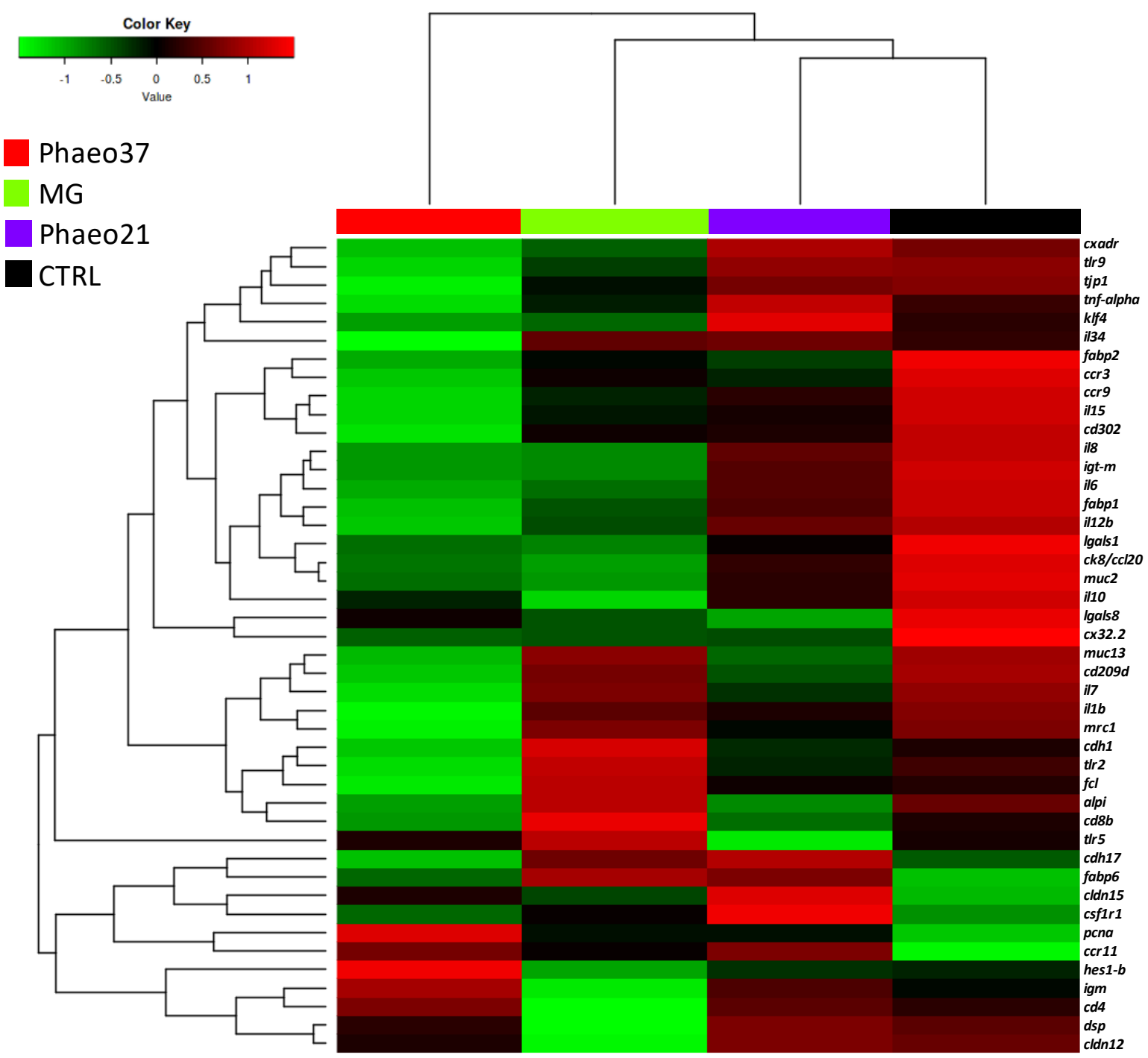

Figure 4. Heat map showing the normalized mRNA levels of selected genes in the anterior intestinal tissue of gilthead seabream juveniles after 8 weeks of feeding. Each block represents the mean mRNA level quantified by qPCR $(n=9)$. 
(A)

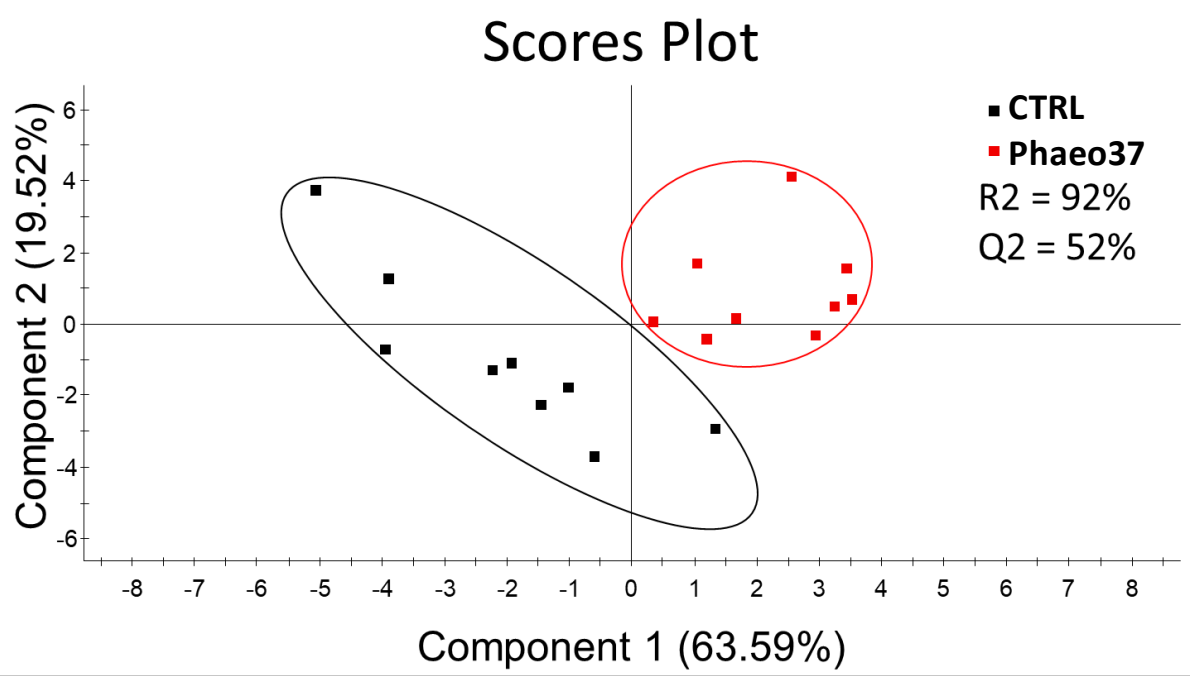

(B)

\begin{tabular}{lc} 
Gene & VIP[2] / FC \\
\hline fcl & $1.38 /-22.72$ \\
$c d 209 d$ & $1.27 /-4.14$ \\
il15 & $1.26 /-3.06$ \\
mrc1 & $1.29 /-2.53$ \\
$c x 32.2$ & $1.71 /-1.91$ \\
il7 & $1.13 /-1.90$ \\
Igt-m & $1.35 /-1.77$ \\
ccr3 & $1.22 /-1.76$ \\
tlr9 & $1.49 /-1.51$ \\
il8 & $1.04 /-1.46$ \\
fabp2 & $1.65 /-1.45$ \\
il12b & $1.14 /-1.40$ \\
fabp1 & $1.10 /-1.34$ \\
ccr9 & $1.18 /-1.32$ \\
il34 & $1.20 /-1.32$ \\
lgals1 & $1.02 /-1.31$ \\
ck8/ccl20 & $1.20 /-1.27$ \\
tjp1 & $1.48 /-1.24$ \\
cxadr & $1.13 /-1.19$ \\
muc13 & $1.02 /-1.11$ \\
\hline
\end{tabular}

Figure 5. (A) Partial least square discriminant analysis (PLS-DA) score plots of all gene expression biomarkers analysed in the proximal intestine of gilthead seabream juveniles along the two main components at 8 weeks. (B) Ordered list of markers by variable importance (VIP) in projection of PLS-DA model for group differentiation, as well as the fold-change (FC) in comparison to CTRL. Markers with VIP values $>1$ after the first and second main components are represented.

\section{Discussion}

Intensive fish production creates stressful conditions that negatively affect immune function [28], increasing the risk of infection caused by opportunistic bacteria. Therefore, preventive strategies that can improve aquatic animal health and reduce the risk of disease outbreaks must be adopted, such as the use of prebiotics and immunostimulants in feed formulation [29-31]. Immunostimulant and prebiotic activities after $\beta-(1,3 ; 1,6)$-glucans administration are well-recognized; thus, these compounds have been suggested as potential nutraceuticals or vaccine adjuvants to enhance immune responses $[4,32,33]$. For that purpose, in the present study, gilthead seabream juveniles were fed microalgae (P. tricornutum) derived BGs in a 2-week cycle pulse-feeding regimen. This nutritional strategy was outlined, as care must be taken not to exhaust the fish immune system due to immunostimulant overexposure after long administration periods [34-37]. Moreover, intermittent administration seems a suitable approach as BGs apparently can induce long-lived effects in fish [38]. Several studies report increased innate immune parameters and pathogen resistance at least 2 weeks after BGs oral and intra-peritoneal (i.p.) administration [22,39,40].

Studies where BGs were orally administered to fish not only showed immunostimulatory effects but in some cases, improved growth performance [23,24,41,42]. Dawood et al. [43] showed that supplementing red seabream diets up to $0.1 \%$ (g/Kg feed) with a commercial BG product ( $85 \%$ purity) for 8 weeks improved final body weight and growth performance as well as lysozyme activity and higher tolerance against a low-salinity stress test when compared with a BG-free fed group. In the current study, $\beta$-glucan supplementation did not affect fish growth performance over the course of the trial ( 8 weeks), independently from its source. However, it did show immunomodulatory effects and improved oxidative 
stress status in accordance with the findings reported in other studies [23,44-47]. Dietary treatments appeared to modulate peripheral lymphocyte numbers. Results pointed to an immunostimulatory effect of diet Phaeo21 at 2 weeks feeding, with this particular BG extract apparently affecting the adaptive arm of the immune system with a rise in circulating lymphocytes. Previous works reported increased lymphocyte percentage in comparison to other leucocytes in pompano fish (Trachinotus Ovatus) fed $0.05 \%$ and $0.10 \%$ [45] and Persian sturgeon (Acipenser persicus) fed 0.2 and $0.3 \%$ yeast BGs [48] for 8 and 6 weeks, respectively. Nonetheless, in the current study, gilthead seabream fed Phaeo21 and MG dietary treatments showed a decrease in circulating lymphocytes percentage compared to those fed CTRL after 8 weeks. Kühlwein, et al. [49] reported no apparent effect on circulating lymphocytes when carp juveniles were fed $0.1,1$ and $2 \%$ yeast BGs continuously for 8 weeks.

On the other hand, non-specific humoral parameters (antiprotease, bactericidal activity and circulating $\operatorname{IgM}$ ) were not affected by the supplementation with $0.06 \%$ BGs from S. cerevisiae or P. tricornutum throughout the experimental period. Accordingly, a study done in gilthead seabream fed a $0.1 \%$ supplemented feed with a macroalgae derived BG (laminarin) did not show changes in serum antiprotease activity and IgM levels after 4 weeks of feeding [23]. Yamamoto et al. [50] tested different levels, ranging from $0 \%$ to $0.8 \%$, of microalgae (Euglena gracilis)-derived BGs in Nile tilapia both in vitro and in vivo. While exposing naïve head-kidney phagocytes directly to BGs facilitated the activation of immune cells increasing bactericidal activity against Streptococcus iniae and superoxide anion production, in vivo immune effects were found to be more moderate. Authors reported increased complement system activity but no effects on serum lysozyme and blood leukocytes respiratory burst. Still, previous studies in fish revealed a tendency of BGs oral administration to stimulate or modulate innate immune parameters [21,22,42,44,51,52].

Reactive oxygen species (ROS) are produced as a normal by-product of cellular metabolism but in excess, they can contribute to increased oxidative stress and cause cellular damage. Antioxidant enzymatic machinery is the principal cellular protective mechanism against oxidative stress in fish tissue [53]. BGs are reported to have antioxidant properties and modulate antioxidant enzymes activity as well as inhibiting lipid peroxidation in mammals [54]. In fish, BG injection increased SOD and CAT activities in the intestine [46] and blood erythrocytes [55], suggesting that BGs could improve anti-oxidative capacity. Accordingly, hepatic lipid peroxidation decreased in Phaeo37- and MG-fed animals at an early stage (2 weeks), while hepatic SOD showed a long-term (8 weeks) stimulation pattern, with the Phaeo37-fed group showing the highest activity. Zeng, et al. [46] reported a correlation between higher mRNA transcription of nuclear factor erythroid 2-related factor 2 (Nrf2) gene and increased SOD and CAT genes transcription, which translated in higher enzyme activity in fish injected with a $0.1 \%$ BG solution. Nrf proteins, under oxidative conditions translocate to the nucleus where they bind to the antioxidant response element (ARE) [56]. ARE is found in the promoters of several chemoprotective genes, including those involved in the response to oxidative stress [57]. Integrating all physiological responses into a multivariate analysis, dietary effects became clearer and differed between sampling points. At 2 weeks of feeding, all groups received BGs clustered together and were different from CTRL. Differences at this early stage pointed to a dietary effect mainly affecting the antioxidant defences and most prominently decreasing lipid peroxidation corroborating results from the one-way ANOVA. Previous studies reported higher antioxidant enzyme activity and lower lipid peroxidation when fish are previously treated with BGs through different administration routes (i.e., i.p. injection; oral route) $[46,55,58]$. After a toxicological insult, pre-treated fish with barley-derived BG were able to prevent intestinal $\mathrm{Cu}$-induced lipid peroxidation [46]. Although BGs from the present study differ in origin and solubility, the observed early ( 2 weeks) beneficial effect was elicited by all BG-supplemented feeds, most likely due to the fact that both soluble and particulate BGs can act as exogenous ROS scavengers. Carballo et al. [59] reported that both a P. tricornutum chrysolaminarin-rich extract (soluble) and a yeast BG (particulate) show ROS scavenger 
activities. At a longer feeding period (8 weeks), the P. tricornutum-derived BG-groups showed higher SOD activity and clustered together independently from CTRL and MG. Furthermore, microalgae BG-treated groups also showed higher thrombocyte numbers. Although both Phaeo21 and 37 diets were supplemented with BG enriched extracts, other compounds such as P. tricornutum cell wall fragments might be present in the mixture and cannot be ruled out as immunomodulators. P. tricornutum cell wall is mainly composed of sulphated polysaccharides [60], which are known to interact with different toll-like receptors (TLRs). These compounds might act as antigens recognized by cell surface receptors activating different leucocyte types. In carp, peripheral thrombocytes constitutively express different TLR genes [61] and have been reported to have phagocytic activity and the ability to ingest particulate antigens possibly acting as an antigen presenting cell [62].

In the present study, at 2 weeks proliferating cell nuclear antigen ( $p c n a)$ gene was down-regulated in the anterior gut of Phaeo37 fed fish. Former studies, report PCNA protein expression inhibition in mammalian cancer cells treated with different glucans including laminarin $[63,64]$. However, intestinal transcriptional changes were more significant at 8 weeks, where differences between CTRL and Phaeo37 gene profiles can be found. Furthermore, Phaeo37 and MG fed groups showed a down-regulation of different genes when compared to CTRL, namely il10, cx32.2, fcl. Hence, a multivariate analysis was performed (PLS-DA) allowing for a more comprehensive understanding of fish health status, whereas, at the same time identifying the most responsive gene biomarkers in fish intestine. VIP analysis with the first two components, highlighted that the top contributing genes for dietary differences in the gut were immune related (PRR- $f c l, c d 209 d, m r c 1, t \operatorname{lr} 9$, $\lg$ gls1; Interleukins- $i l 7, i l 8, i l 12 \beta, i l 15$, il34; Immunoglobulin production- igt- $m$; chemokines and receptors- $c c r 3, c c r 9, c k 8 / c l 20)$. Phaeo37 dietary treatment caused a general down-regulation of gene transcription. Therefore, the effect of Phaeo37 supplemented diet was mostly immunomodulatory inducing a local anti-inflammatory state at molecular level, which as a consequence led to decreased immune cell activation in the gut. The down-regulation of intestinal immune-related genes can be understood as an immune tolerance effect that can be beneficial in an acute inflammation scenario, counterbalancing its negative and potentially dangerous effects. Falco et al. [25] also found an anti-inflammatory effect in common carp (Cyprinius carpio L.) intestine, with several inflammatory genes appearing down regulated when fish were fed a yeast BG supplemented diet for a 2-week period. Furthermore, even after a challenge (i.p. injection) with live bacteria (Aeromonas salmonicida), fish fed BGs showed decreased intestinal il1b, il6 and tnf-alpha expression, while showing up-regulation in the head-kidney. In this particular case, it seems that BG may be preventing an acute response to infection in the gut, without compromising the systemic response. Additionally, the same down-regulation pattern (inflammatory genes) was seen in the spleen of rainbow trout after 37 days of feeding lentinan (soluble low molecular weight glucan)-supplemented diets [65]. These findings support the idea that BG can have localized specific effects depending on the target tissue.

Overall, some discrepancies can be observed among previous works and data gathered in the present study, which can be explained by different BG preparations. While some studies use crude BG extracts, others use purified compounds differing in molecular weight, branching and solubility. BGs solubility/insolubility seems to play a major role in ligand/receptor recognition and consequently immune cell activation $[66,67]$. In mammals, particulate BGs directly stimulate immune cell activation through a Dectin-1 recognition pathway, while soluble $B G$ require complement-mediated opsonisation to activate a CR3-dependent pathway [66,68]. Still, in the present work, the particulate BG diet (MG) showed only mild effects mostly related with oxidative defenses after 2 weeks of feeding. In addition to solubility, molecular weight can play an important role in the biological effects of BGs. Different authors have found that in colitis-induced rat models, the dietary administration of low and high molecular weight oat BGs reduced the inflammatory response in colon and also ameliorated the local inflammation [69,70]. However, these authors found that low molecular mass BGs showed a significantly stronger anti- 
inflammatory effect, through the down-regulation of several pro-inflammatory cytokines and that the therapeutic effect is in evident relation with the molecular mass of the polymer. When comparing the different feeds used in the present study, Phaeo21 and 37 extracts show low molecular mass BGs (chrysolaminarin) [10] while, MG feed is supplemented with a high molecular weight BG (Baker's yeast) [71,72]. Furthermore, P. tricornutum extract supplemented diets although having the same BG concentration, differ in purity, since Phaeo37 extract has a higher percentage of BGs compared to Phaeo21. Thus, the combination of low molecular mass BGs and higher extract purity might explain the higher overall immunomodulatory and oxidative protective effects of Phaeo37 dietary treatment.

In summary, novel feeds with increasingly higher percentages of terrestrial animaland plant-derived ingredients have been shown to have anti-nutritional factors that often cause gut inflammation in fish, a condition that might lead to impaired nutrient absorption and the disruption of normal microbiota. The use of gut anti-inflammatory compounds can have special relevance nowadays in aquaculture, both as a prophylactic and therapeutic measure, as the industry decreases the use of FM, replacing it by the ingredients referred to above. In this regard, our results indicate that the dietary administration of a P. tricornutum $37 \%$ enriched-BG extract might be relevant in a context of extreme dietary formulation due to its anti-inflammatory and anti-oxidative effects.

\section{Materials and Methods}

\subsection{P. tricornutum Extracts}

Chrysolaminarin-rich biomass from P. tricornutum (SAG 1090-1b) grown under nitrogendepleted conditions in flat panel airlift reactors was harvested and concentrated via centrifugation to 250-270 $\mathrm{g} \mathrm{L}^{-1}$ (Clara 20, Alfa Laval, Lund, Sweden). Afterwards, the biomass was frozen at $-20{ }^{\circ} \mathrm{C}$. For further processing, the biomass was thawed and diluted to $100 \mathrm{~g} \mathrm{~L}^{-1}$ with deionized water. The cell disruption was performed according to Derwenskus, et al. [73] with a ball mill (PML-2, Bühler, Uzwil, Switzerland). Phaeo21 was freeze dried after cell disruption (VaCo 5, Zirbus, Bad Grund, Germany), while Phaeo37 was centrifuged and the supernatant freeze-dried (Avanti J-26 XP, Beckman Coulter, Brea, CA, USA).

\subsection{Diet Composition}

The trial comprised four isonitrogenous (63\% crude protein) and isolipidic (17\% crude fat) diets (Table 4). A high-quality, practical diet was used as control (CTRL) and 3 experimental diets based on CTRL were supplemented with either a commercial product derived from S. cerevisiae (diet MG) or different extracts of P. tricornutum (diets Phaeo21 and Phaeo37), to obtain a final concentration of $0.6 \mathrm{~g} \beta$-glucans per $\mathrm{Kg}$ of feed $(0.06 \%)$ in all supplemented diets. Diets were manufactured by SPAROS. All powder ingredients were mixed according to the target formulation in a double-helix mixer (model RM90, MAINCA, Barcelona, Spain) and ground (below $200 \mu \mathrm{m}$ ) in a micropulverizer hammer mill (model SH1, Hosokawa-Alpine, Augsburg, Germany). Subsequently, the oils were added to the mixtures, which were humidified with 20-25\% water and agglomerated by a low-shear and low-temperature extrusion process (ITALPLAST, West Heidelberg, VIC, Australia). Extruded pellets $(1.5 \mathrm{~mm}$ ) were dried in a vibrating fluid bed dryer (model DR100, TGC Extrusion, Roullet-Saint-Estèphe, France). Diets were packed in sealed plastic buckets and shipped to the research site (Riasearch, Murtosa, Portugal) where they were stored at room temperature in a cool and aerated emplacement. Samples of each diet were taken for analytical characterization. 
Table 4. Ingredients and proximate composition of experimental diets.

\begin{tabular}{|c|c|c|c|c|}
\hline Ingredients \% & CTRL & MG & Phaeo21 & Phaeo37 \\
\hline Fishmeal $^{1}$ & 20.00 & 20.00 & 20.00 & 20.00 \\
\hline Fish protein hydrolysate ${ }^{2}$ & 8.00 & 8.00 & 8.00 & 8.00 \\
\hline Squid meal ${ }^{3}$ & 21.00 & 21.00 & 21.00 & 21.00 \\
\hline Krill meal ${ }^{4}$ & 16.50 & 16.50 & 16.50 & 16.50 \\
\hline Wheat gluten ${ }^{5}$ & 11.50 & 11.50 & 11.50 & 11.50 \\
\hline Wheat meal 6 & 0.29 & 0.19 & & 0.13 \\
\hline Vitamin and mineral premix ${ }^{7}$ & 2.00 & 2.00 & 2.00 & 2.00 \\
\hline Lecithin $^{8}$ & 4.30 & 4.30 & 4.30 & 4.30 \\
\hline Fish oil $^{9}$ & 6.50 & 6.50 & 6.50 & 6.50 \\
\hline Binders, antioxidant and other additives 10 & 9.91 & 9.91 & 9.91 & 9.91 \\
\hline Yeast beta-glucans ${ }^{11}$ & & 0.10 & & \\
\hline Algae beta-glucans Phaeo21 ${ }^{12}$ & & & 0.29 & \\
\hline Algae beta-glucans Phaeo37 13 & & & & 0.16 \\
\hline \multicolumn{5}{|l|}{ Proximate composition } \\
\hline Dry matter (DM) \% & 94.60 & 94.20 & 94.20 & 94.50 \\
\hline Ash, \% DM & 9.60 & 9.50 & 9.50 & 9.50 \\
\hline Crude protein, \% DM & 62.90 & 62.80 & 62.80 & 62.90 \\
\hline Crude fat, \% DM & 17.10 & 17.10 & 17.10 & 17.10 \\
\hline Gross energy ( $\left.\mathrm{kJ} \mathrm{g}^{-1} \mathrm{DM}\right)$ & 22.90 & 22.90 & 22.90 & 22.90 \\
\hline
\end{tabular}

${ }^{1}$ Super Prime: $66.3 \%$ CP, 11.5\% CF, Pesquera Diamante, Peru; ${ }^{2}$ CPSP 90: 82\% CP 9\% CF, Sopropêche, France ${ }^{3}$ Squid meal without guts: $83 \%$ CP, $4 \%$ CF, Sopropêche, France; ${ }^{4}$ Krill meal: $61.1 \%$ CP, $17.4 \%$ CF, Aker Biomarine, Norway; ${ }^{5}$ VITEN: $82 \%$ CP, $2.1 \%$ CF, Roquette, France; ${ }^{6}$ Wheat meal: $10.2 \%$ CP; $1.2 \%$ CF, MOLISUR, Spain; 7 PREMIX Lda, Portugal: Vitamins (IU or $\mathrm{mg} / \mathrm{kg}$ diet): DL-alpha tocopherol acetate, $200 \mathrm{mg}$; sodium menadione bisulphate, $50 \mathrm{mg}$; retinyl acetate, 40,000 IU; DL-cholecalciferol, $4000 \mathrm{IU}$; thiamin, $60 \mathrm{mg}$; riboflavin, $60 \mathrm{mg}$; pyridoxine, $40 \mathrm{mg}$; cyanocobalamin, $0.2 \mathrm{mg}$; nicotinic acid, $400 \mathrm{mg}$; folic acid, $30 \mathrm{mg}$; ascorbic acid, $1000 \mathrm{mg}$; inositol, $1000 \mathrm{mg}$; biotin, $6 \mathrm{mg}$; calcium panthotenate, $200 \mathrm{mg}$; choline chloride, $2000 \mathrm{mg}$, betaine, $1000 \mathrm{mg}$ Minerals (g or mg/kg diet): copper sulphate, $18 \mathrm{mg}$; ferric sulphate, $12 \mathrm{mg}$; potassium iodide, $1 \mathrm{mg}$; manganese oxide, $20 \mathrm{mg}$; sodium selenite, $0.02 \mathrm{mg}$; zinc sulphate, $27.5 \mathrm{mg}$; sodium chloride, $800 \mathrm{mg}$; excipient wheat middling's; ${ }^{8}$ LECICO GmbH, Germany; ${ }^{9}$ Sopropêche, France; ${ }^{10}$ Confidential blend of constant binders and other additives; ${ }^{11}$ Macrogard, $67.2 \%$ beta-glucans, Biorigin, Brazil; ${ }^{12}$ Beta-glucan rich biomass of microalgae (Phaeodactylum tricornutum from SAG culture collection) with $21 \%$ beta-glucans; ${ }^{13}$ Beta-glucan rich extract of microalgae (Phaeodactylum tricornutum from SAG culture collection) with $37 \%$ beta-glucans.

\subsection{Fish Rearing Conditions and Feeding Trial}

Fish were reared in a seawater recirculation system with aeration (mean dissolved oxygen above $6 \mathrm{mg} \mathrm{L}^{-1}$ ) and water flow at $3 \mathrm{~L} \mathrm{~min}^{-1}$ (mean temperature $24.1 \pm 0.6{ }^{\circ} \mathrm{C}$; mean salinity $18.7 \pm 0.1 \%$ ). Water quality parameters were monitored daily (mean dissolved oxygen $6.4 \pm 1.0 \mathrm{mg} \mathrm{L}^{-1}$; mean unionized ammonia levels $0.001 \pm 0.002 \mathrm{mg} \mathrm{L}^{-1}$ ). Diets were randomly assigned to quadruplicate groups of 95 gilthead seabream juveniles (initial body weight: $4.1 \pm 0.1 \mathrm{~g}$ ) that were fed to satiation three times a day for 8 weeks in a pulse-feeding regimen. Accordingly, in fish fed the different experimental diets, the CTRL diet was intercalated every 2 weeks, as shown in Figure 6.

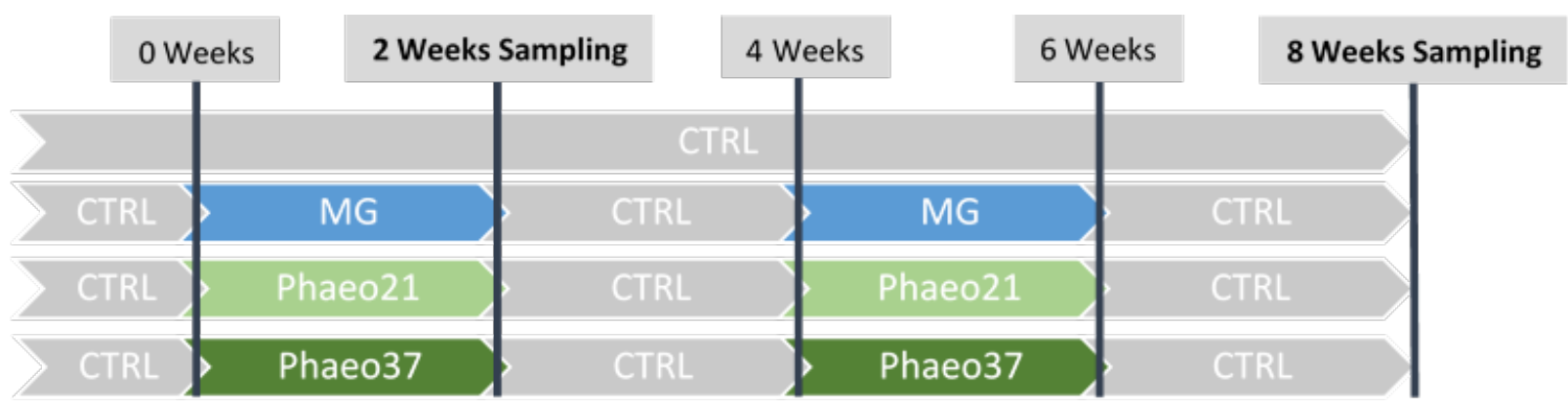

Figure 6. Schematic overview of the experimental design. 


\subsection{Sampling Procedures}

Fish were individually weighed at the beginning and after 2 and 8 weeks of the feeding trial and feed consumption for each experimental replicate was registered daily. After 2 and 8 weeks, three fish per tank were euthanized with a 2-phenoxyethanol lethal dose $\left(0.5 \mathrm{~mL} \mathrm{~L}^{-1}\right)$ [74], weighed and sampled for tissues (blood, head-kidney, liver and gut). Blood was collected from the caudal vein using heparinized syringes and centrifuged at $10,000 \times g$ during $10 \mathrm{~min}$ at $4{ }^{\circ} \mathrm{C}$ to obtain plasma samples. Plasma, head-kidney and liver samples were immediately frozen at $-80^{\circ} \mathrm{C}$, and anterior intestine was preserved in RNA later until further analysis.

\subsection{Haematological Procedures}

Blood smears were prepared from peripheral blood, air dried and stained with Wright's stain (Haemacolor; Merck) after fixation for $1 \mathrm{~min}$ with formol-ethanol (10\% formaldehyde in ethanol). Neutrophils were labelled through the detection of peroxidase activity revealed by the Antonow's technique described by Afonso, et al. [75]. The slides were examined under oil immersion $(1000 \times)$, and at least 200 leucocytes were counted and classified as thrombocytes, lymphocytes, monocytes and neutrophils. The relative percentage of each cell type was calculated.

\subsection{Innate Humoral Parameters}

Plasma bactericidal activity was determined following the method described by Machado, et al. [76] with some modifications. Edwardsiella tarda (E. tarda) strain ACC 53.1, gently provided by Prof. Alicia Toranzo (University of Santiago, Spain) was used in the protocol. Briefly, $20 \mu \mathrm{L}$ of plasma were mixed with $20 \mu \mathrm{L}$ of bacteria suspension $\left(10^{8} \mathrm{CFU} \mathrm{mL}{ }^{-1}\right)$ in duplicate in a flat-bottom 96-well plate that was incubated for $2.5 \mathrm{~h}$ at $25{ }^{\circ} \mathrm{C}$ (positive control: $20 \mu \mathrm{L}$ of TSB instead of plasma). Afterwards, $25 \mu \mathrm{L}$ of 3-(4,5 dimethyl-2-yl)-2,5-diphenyl tetrazolium bromide (1 $\mathrm{mg} \mathrm{mL}^{-1}$; Sigma, St. Louis, MO, USA) was added to each well and incubated for $10 \mathrm{~min}$ at $25^{\circ} \mathrm{C}$ to allow the formation of formazan precipitates. Plates were then centrifuged at $2000 \times g$ for $10 \mathrm{~min}$, the supernatant was discarded and the precipitate was dissolved in $200 \mu \mathrm{L}$ of dimethyl sulfoxide (Sigma, St. Louis, MO, USA). The absorbance was then measured at $560 \mathrm{~nm}$. Bactericidal activity is expressed as a percentage calculated from the difference between surviving bacteria compared to the number of bacteria from positive controls (100\%).

Anti-protease activity was determined as described by Ellis et al. [77] with some modifications. Briefly, $10 \mu \mathrm{L}$ of plasma were incubated with the same volume of trypsin solution $\left(5 \mathrm{mg} \mathrm{mL}^{-1}\right.$ in $\left.\mathrm{NaHCO}_{3}, 5 \mathrm{mg} \mathrm{mL}^{-1}, \mathrm{pH} 8.3\right)$ for $10 \mathrm{~min}$ at $22^{\circ} \mathrm{C}$. After incubation, $100 \mu \mathrm{L}$ of phosphate buffer $\left(\mathrm{NaH}_{2} \mathrm{PO}_{4}, 13.9 \mathrm{mg} \mathrm{mL}^{-1}, \mathrm{pH} 7.0\right)$ and $125 \mu \mathrm{L}$ of azocasein solution ( $20 \mathrm{mg} \mathrm{mL}^{-1}$ in $\mathrm{NaHCO}_{3}, 5 \mathrm{mg} \mathrm{mL}^{-1}, \mathrm{pH}$ 8.3) were added and incubated for $1 \mathrm{~h}$ at $22{ }^{\circ} \mathrm{C}$. Finally, $250 \mu \mathrm{L}$ of trichloroacetic acid were added to the reaction mixture and incubated for $30 \mathrm{~min}$ at $22{ }^{\circ} \mathrm{C}$. The mixture was centrifuged at $10,000 \times g$ for $5 \mathrm{~min}$ at room temperature. Afterwards, $100 \mu \mathrm{L}$ of the supernatant was transferred to a 96-well plate and mixed with $100 \mu \mathrm{L}$ of $\mathrm{NaOH}\left(40 \mathrm{mg} \mathrm{mL}^{-1}\right)$. The OD was read at $450 \mathrm{~nm}$ in a Synergy HT microplate reader. Phosphate buffer instead of plasma and trypsin served as blank, whereas the reference sample was phosphate buffer instead of plasma. The sample inhibition percentage of trypsin activity was calculated as follows: $100-(($ sample absorbance/reference absorbance) $\times 100$ ). All analyses were conducted in duplicate.

Plasma immunoglobulins (IgMs) were measured by an ELISA assay. Briefly, plasma samples were diluted (1:100) in $\mathrm{Na}_{2} \mathrm{CO}_{3}(50 \mathrm{mM}, \mathrm{pH}=9.6)$. Diluted plasma samples $\left(100 \mu \mathrm{L}\right.$ in duplicate) were incubated overnight $\left(4^{\circ} \mathrm{C}\right)$ in a 96 well plate, using $\mathrm{Na}_{2} \mathrm{CO}_{3}$ $(100 \mu \mathrm{L})$ as a negative control. The samples (antigen) were then removed and $300 \mu \mathrm{L}$ of blocking buffer ( $5 \%$ low fat milk in $0.1 \%$ Tween 20 ) was added to each well and incubated for $1 \mathrm{~h}$ at $22{ }^{\circ} \mathrm{C}$. This mixture was then removed, followed by three consecutive washes with $300 \mu \mathrm{L}$ of T-TBS (0.1\% Tween 20). After properly cleaning and drying the wells, $100 \mu \mathrm{L}$ of the anti-seabream primary IgM monoclonal antibody (1:200 dilution in blocking buffer; 
Aquatic Diagnostics, UK) was added to each well and incubated for $1 \mathrm{~h}$ at $22{ }^{\circ} \mathrm{C}$. The primary antibody was then removed by aspiration, with three consecutive washes being performed. Afterwards, the anti-mouse IgG-HRP, secondary antibody (1:1000 dilution in blocking buffer; SIGMA), was added and incubated for $1 \mathrm{~h}$ at $22^{\circ} \mathrm{C}$, then removed by aspiration. The wells were again washed three times and $100 \mu \mathrm{L}$ of TMB substrate solution for ELISA (BioLegend \#421101), was added to each well and incubated for $5 \mathrm{~min}$. The reaction was stopped after $5 \mathrm{~min}$ by adding $100 \mu \mathrm{L}$ of $\mathrm{H}_{2} \mathrm{SO}_{4} 2 \mathrm{M}$ and the optical density was read at $450 \mathrm{~nm}$.

\subsection{Analysis of Oxidative Stress Biomarkers}

Liver samples were thawed and homogenized (1:10) in phosphate buffer $0.1 \mathrm{M}$ (pH 7.4) using Precellys evolution tissue lyser homogenizer.

One aliquot of tissue homogenate was used to determine the extent of endogenous lipid peroxidation (LPO) by measuring thiobarbituric acid-reactive species (TBARS) as suggested by Bird and Draper [78]. To prevent artifactual lipid peroxidation, butylhydroxytoluene (BHT $0.2 \mathrm{mM}$ ) was added to the aliquot. Briefly, $1 \mathrm{~mL}$ of $100 \%$ trichloroacetic acid and $1 \mathrm{~mL}$ of $0.73 \%$ thiobarbituric acid solution (in Tris- $\mathrm{HCl} 60 \mathrm{mM} \mathrm{pH} 7.4$ with DTPA $0.1 \mathrm{mM}$ ) were added to $0.2 \mathrm{~mL}$ of liver homogenate. After incubation at $100{ }^{\circ} \mathrm{C}$ for $60 \mathrm{~min}$, the solution was centrifuged at $12,000 \times g$ for $5 \mathrm{~min}$ and LPO levels were determined at $535 \mathrm{~nm}$.

The remaining tissue homogenate was centrifuged for $20 \mathrm{~min}$ at $10,000 \times g\left(4^{\circ} \mathrm{C}\right)$ to obtain the post mitochondrial supernatant fraction (PMS). Total proteins in homogenates were measured by using Pierce ${ }^{\mathrm{TM}} \mathrm{BCA}$ Protein Assay Kit, as described by the manufacturer.

Catalase (CAT) activity was determined in PMS by measuring substrate $\left(\mathrm{H}_{2} \mathrm{O}_{2}\right)$ consumption at $240 \mathrm{~nm}$ according to Claiborne [79] adapted to microplate. Briefly, in a microplate well, $0.140 \mathrm{~mL}$ of phosphate buffer $(0.05 \mathrm{M} \mathrm{pH} 7.0)$ and $0.150 \mathrm{~mL} \mathrm{H}_{2} \mathrm{O}_{2}$ solution (30 mM in phosphate buffer $0.05 \mathrm{M} \mathrm{pH} \mathrm{7.0)} \mathrm{were} \mathrm{added} \mathrm{to} 0.01 \mathrm{~mL}$ of liver PMS $\left(0.7 \mathrm{mg} \mathrm{ml}^{-1}\right.$ total protein). Enzymatic activity was determined in a microplate reader (BioTek Synergy HT) reading the optical density at $240 \mathrm{~nm}$ for 2 min every $15 \mathrm{sec}$ interval.

Superoxide dismutase (SOD) activity was measured according to Flohé and Otting [80] adapted to microplate by Lima, et al. [81]. Briefly, in a microplate well, $0.2 \mathrm{~mL}$ of the reaction solution [1 part xantine solution $0.7 \mathrm{mM}$ (in NaOH $1 \mathrm{mM}$ ) and 10 parts cytochrome c solution $0.03 \mathrm{mM}$ (in phosphate buffer $50 \mathrm{mM} \mathrm{pH} 7.8$ with $1 \mathrm{mM}$ Na-EDTA)] was added to $0.05 \mathrm{~mL}$ of liver PMS (0.25 mg ml $\mathrm{m}^{-1}$ total protein). Optical density was measured at $550 \mathrm{~nm}$ in a microplate reader (BioTek Synergy HT, Winooski, VT, USA) every 20-s interval for $3 \mathrm{~min}$ at $25^{\circ} \mathrm{C}$.

Total glutathione (tGSH) content was determined with PMS fraction at $412 \mathrm{~nm}$ using a recycling reaction of reduced glutathione (GSH) with 5,5-dithiobis-(2-nitrobenzoic acid) (DTNB) in the presence of glutathione reductase (GR) excess [82,83]. TG content is calculated as the rate of $\mathrm{TNB}^{2-}$ formation with an extinction coefficient of DTNB chromophore formed, $\varepsilon=14.1 \times 10^{3} \mathrm{M}^{-1} \mathrm{~cm}^{-1}$.

\subsection{Gene Expression}

Total RNA isolation from target tissue (anterior intestine) was conducted with NZY Total RNA Isolation kit (NZYTech, Lisbon, Portugal) following the manufacturer's specifications. Reverse transcription (RT) of $500 \mathrm{ng}$ total RNA was performed with random decamers using a High-Capacity cDNA Reverse Transcription Kit (Applied Biosystems, Foster City, CA, USA) according to the manufacturer's instructions. RT reactions were incubated for $10 \mathrm{~min}$ at $25^{\circ} \mathrm{C}$ and $2 \mathrm{~h}$ at $37^{\circ} \mathrm{C}$. Negative control reactions were run without reverse transcriptase. Real-time quantitative PCR was carried out on a EpMotion 5070 Liquid Handling Robot (Eppendorf, Hamburg, Germany) using a 96-well PCR array layout with 44 genes designed for simultaneously profiling of anterior intestine (Table 5). Genes comprised in the array were selected for their involvement in gut integrity, health, immunity and signal transduction. Specific primer pair sequences are listed in Table S3. 
Controls of general PCR performance were included on each array, and all the pipetting operations performed by means of the EpMotion 5070 Liquid Handling Robot (Eppendorf, Hamburg, Germany). Briefly, RT reactions were diluted to obtain the equivalent concentration of $660 \mathrm{pg}$ of total input RNA which were used in a $25-\mu \mathrm{L}$ volume for each PCR reaction. PCR wells contained a $2 \times$ SYBR Green Master Mix (Bio-Rad) and specific primers at a final concentration of $0.9 \mu \mathrm{M}$ were used to obtain amplicons 50-150 bp in length. The program used for PCR amplification included an initial denaturation step at $95{ }^{\circ} \mathrm{C}$ for $3 \mathrm{~min}$, followed by 40 cycles of denaturation for $15 \mathrm{~s}$ at $95^{\circ} \mathrm{C}$ and annealing/extension for $60 \mathrm{~s}$ at $60^{\circ} \mathrm{C}$. The efficiency of PCR reactions was always higher than $90 \%$, and negative controls without sample templates were routinely performed for each primer set. The specificity of reactions was verified by analysis of melting curves (ramping rates of $0.5^{\circ} \mathrm{C} / 10 \mathrm{~s}$ over a temperature range of $55-95^{\circ} \mathrm{C}$ ), and linearity of serial dilutions of RT reactions. Fluorescence data acquired during the PCR extension phase were normalized using the delta-delta $\mathrm{Ct}$ method [84]. Beta-actin $(a c t b)$ was tested for gene expression stability using GeNorm software $(\mathrm{M}$ score $=0.13$ ) and it was used as housekeeping gene in the normalization procedure. For comparing the mRNA expression level of a panel of genes in a given dietary treatment, all data values were in reference to the expression level of claudin 12 (cldn12) in CTRL fish, which was arbitrarily assigned a value of 1 .

Table 5. PCR-array layout for gene expression profiling of anterior intestine in seabream.

\begin{tabular}{|c|c|c|c|}
\hline Function & Gene & Symbol & GenBank \\
\hline \multirow[t]{11}{*}{ Epithelia integrity } & proliferating cell nuclear antigen & pcna & KF857335 \\
\hline & transcription factor HES-1-B & hes1-b & KF857344 \\
\hline & krueppel-like factor 4 & klf4 & KF857346 \\
\hline & claudin-12 & $\operatorname{cldn} 12$ & KF861992 \\
\hline & claudin-15 & cldn15 & KF861993 \\
\hline & cadherin-1 & $c d h 1$ & KF861995 \\
\hline & cadherin-17 & cdh17 & KF861996 \\
\hline & tight junction protein $\mathrm{ZO}-1$ & tjp1 & KF861994 \\
\hline & desmoplakin & $d s p$ & KF861999 \\
\hline & gap junction $\mathrm{C} \times 32.2$ protein & $c x 32.2$ & KF862000 \\
\hline & coxsackievirus and adenovirus receptor homolog & cxadr & KF861998 \\
\hline \multirow[t]{4}{*}{ Nutrient transport } & intestinal-type alkaline phosphatase & alpi & KF857309 \\
\hline & liver type fatty acid-binding protein & fabp1 & KF857311 \\
\hline & intestinal fatty acid-binding protein & fabp2 & KF857310 \\
\hline & ileal fatty acid-binding protein & fabp 6 & KF857312 \\
\hline \multirow[t]{2}{*}{ Mucus production } & mucin 2 & muc2 & JQ277710 \\
\hline & mucin 13 & muc13 & JQ277713 \\
\hline \multirow[t]{9}{*}{ Interleukins } & tumor necrosis factor-alpha & tnf-alpha & AJ413189 \\
\hline & interleukin 1 beta & $i l 1 b$ & AJ419178 \\
\hline & interleukin 6 & $i l 6$ & EU244588 \\
\hline & interleukin 7 & $i l 7$ & JX976618 \\
\hline & interleukin 8 & $i l 8$ & JX976619 \\
\hline & interleukin 10 & $i l 10$ & JX976621 \\
\hline & interleukin 12 subunit beta & $i l 12 b$ & JX976624 \\
\hline & interleukin 15 & $i l 15$ & JX976625 \\
\hline & interleukin 34 & il34 & JX976629 \\
\hline \multirow[t]{7}{*}{ Cell markers } & cluster differentiation 4 & $c d 4$ & AM489485 \\
\hline & cluster differentiation 8 beta & $c d 8 b$ & KX231275 \\
\hline & C-C chemokine receptor 3 & ccr3 & KF857317 \\
\hline & C-C chemokine receptor 9 & $\operatorname{ccr} 9$ & KF857318 \\
\hline & C-C chemokine receptor 11 & ccr11 & KF857319 \\
\hline & $\mathrm{C}-\mathrm{C}$ chemokine $\mathrm{ck} 8 / \mathrm{C}-\mathrm{C}$ motif chemokine ligand 20 & ck8/ ccl20 & GU181393 \\
\hline & macrophage colony-stimulating factor 1 receptor & csf1r & AM050293 \\
\hline \multirow[t]{2}{*}{ Ig production } & immunoglobulin $\mathrm{M}$ & $i g m$ & JQ811851 \\
\hline & immunoglobulin T membrane-bound form & igt-m & KX599201 \\
\hline
\end{tabular}


Table 5. Cont.

\begin{tabular}{|c|c|c|c|}
\hline Function & Gene & Symbol & GenBank \\
\hline \multirow{9}{*}{$\begin{array}{l}\text { Pathogen associated } \\
\text { microbial pattern } \\
\text { (PAMP) }\end{array}$} & galectin 1 & lgals1 & KF862003 \\
\hline & galectin 8 & lgals8 & KF862004 \\
\hline & toll like receptor 2 & tlr2 & KF857323 \\
\hline & toll like receptor 5 & $\operatorname{tlr} 5$ & KF857324 \\
\hline & toll like receptor 9 & tlrg & AY751797 \\
\hline & CD209 antigen-like protein D & $c d 209 d$ & KF857327 \\
\hline & CD302 antigen & $c d 302$ & KF857328 \\
\hline & macrophage mannose receptor 1 & $m r c 1$ & KF857326 \\
\hline & fucolectin & $f_{c l}$ & KF857331 \\
\hline
\end{tabular}

\subsection{Data Analysis}

All results are expressed as mean \pm standard error (mean \pm SE). Residuals were tested for normality (Shapiro-Wilk's test) and homogeneity of variance (Levene's test). When residuals did not meet the assumptions, data were transformed by a Box-Cox transformation. One-way ANOVAs were performed for all datasets, with "dietary treatment" as the fixed effect, followed by multiple comparison Tukey post-hoc tests. The factor "time" was not considered in the analysis since it is not a goal of the study to evaluate how time affects the measured variables, and groups were treated independently for 2 and 8 weeks.

In an attempt to discriminate and classify individuals by the existing groups, a multivariate canonical discriminant analysis was performed on the physiological dataset (obtained from blood, plasma and liver tissues analyses) to evaluate the linear combinations of the original variables that will best separate the groups (discriminant functions). Each discriminant function explains part of total variance of the dataset and is loaded by variables contributing the most for that variation. Discriminatory effectiveness was assessed by Wilk's $\lambda$ test, and the distance between groups' centroids was measured by squared Mahalanobis distance, and Fisher's F statistic was applied to infer significance. All statistical analyses were performed using the computer package SPSS 26 for WINDOWS.

Gene expression results were evaluated with an unsupervised multivariate analysis by principal component analysis (PCA) as an unbiased statistical method to observe intrinsic trends in the dataset, using EZ-INFO ${ }^{\circledR}$ v3.0 (Umetrics, Sweden). To achieve the maximum separation among the groups, a supervised multivariate analysis by partial least-squares discriminant analysis (PLS-DA) was sequentially applied, using EZ-INFO ${ }^{\circledR}$ v3.0 (Umetrics, Umeå, Sweden). Potential differential genes were selected according to the Variable Importance in the Projection (VIP) values. Variables with VIP $>1$ were considered to be influential for the separation of samples in PLS-DA analysis [85-87]. The level of significance used was $p \leq 0.05$ for all statistical tests. Heat map of transcript levels were produced with the $\mathrm{R}$ package gplots, using the average linkage method and Euclidean distance.

Supplementary Materials: The following are available online at https:/ / www.mdpi.com/article/10.3 390/md19120653/s1, Table S1. Relative gene expression profiling of anterior intestine in gilthead seabream juveniles fed experimental diets for 2 weeks; Table S2. Relative gene expression profiling of anterior intestine in gilthead seabream juveniles fed experimental diets for 8 weeks; Table S3: Primers for qPCR amplification in seabream.

Author Contributions: Conceptualization, B.R., M.S., L.E.C.C., R.S., J.D. and B.C.; Data curation, B.R., A.T.G., J.P.-S. and J.C.-G.; Formal analysis, B.R., A.T.G., P.S., J.P.-S. and J.C.-G.; Funding acquisition, L.E.C.C., U.S.-S., J.D. and B.C.; Investigation, B.R., P.S., R.S., U.S.-S. and K.F.; Project administration, J.D. and B.C.; Resources, U.S.-S. and K.F.; Supervision, L.E.C.C., J.D. and B.C.; Writing-original draft, B.R.; Writing-review and editing, A.T.G., M.S., L.E.C.C., R.S., J.P.-S., J.C.-G., U.S.-S., J.D. and B.C. All authors have read and agreed to the published version of the manuscript. 
Funding: This work has received funding from the Bio Based Industries Joint Undertaking (BBI JU) under the European Union's Horizon 2020 research and innovation programme under grant agreement No. 745754 (project MAGNIFICENT). This output reflects the views only of the author(s), and the European Union and BBI JU cannot be held responsible for any use which may be made of the information contained therein. This work is also a result of the project ATLANTIDA (ref. NORTE-01-0145-FEDER-000040), supported by the Norte Portugal Regional Operational Programme (NORTE 2020), under the PORTUGAL 2020 Partnership Agreement and through the European Regional Development Fund (ERDF), and by national funds through FCT-Foundation for Science and Technology within the scope of UIDB/04423/2020 and UIDP/04423/2020. BR and BC were supported by FCT (PD/BDE/129262/2017 and IF/00197/2015, respectively).

Institutional Review Board Statement: The experiment was carried out in compliance with the Guidelines of the European Union Council (Directive 2010/63/EU) and Portuguese legislation for the use of laboratory animals at Riasearch facilities (Portugal).

Informed Consent Statement: Not applicable.

Data Availability Statement: Not applicable.

Conflicts of Interest: The authors declare that they have no known competing financial interests or personal relationships that could have appeared to influence the work reported in this paper.

\section{References}

1. Van Boeckel, T.P.; Brower, C.; Gilbert, M.; Grenfell, B.T.; Levin, S.A.; Robinson, T.P.; Teillant, A.; Laxminarayan, R. Global trends in antimicrobial use in food animals. Proc. Natl. Acad. Sci. USA 2015, 112, 5649-5654. [CrossRef] [PubMed]

2. Meena, D.K.; Das, P.; Kumar, S.; Mandal, S.C.; Prusty, A.K.; Singh, S.K.; Akhtar, M.S.; Behera, B.K.; Kumar, K.; Pal, A.K.; et al. Beta-glucan: An ideal immunostimulant in aquaculture (a review). Fish Physiol. Biochem. 2013, 39, 431-457. [CrossRef]

3. Adams, A. Progress, challenges and opportunities in fish vaccine development. Fish Shellfish Immunol. 2019, 90, 210-214. [CrossRef]

4. Song, S.K.; Beck, B.R.; Kim, D.; Park, J.; Kim, J.; Kim, H.D.; Ringø, E. Prebiotics as immunostimulants in aquaculture: A review. Fish Shellfish Immunol. 2014, 40, 40-48. [CrossRef] [PubMed]

5. Yilmaz, S.; Yilmaz, E.; Dawood, M.A.O.; Ringø, E.; Ahmadifar, E.; Abdel-Latif, H.M.R. Probiotics, prebiotics, and synbiotics used to control vibriosis in fish: A review. Aquaculture 2022, 547, 737514. [CrossRef]

6. Guedes, A.C.; Amaro, H.M.; Malcata, F.X. Microalgae as sources of high added-value compounds-a brief review of recent work. Biotechnol. Prog. 2011, 27, 597-613. [CrossRef] [PubMed]

7. Nazih, H.; Bard, J.-M. Chapter 10-Microalgae in Human Health: Interest as a Functional Food. In Microalgae in Health and Disease Prevention; Levine, I.A., Fleurence, J., Eds.; Academic Press: Cambridge, MA, USA, 2018; pp. 211-226.

8. Molino, A.; Iovine, A.; Casella, P.; Mehariya, S.; Chianese, S.; Cerbone, A.; Rimauro, J.; Musmarra, D. Microalgae Characterization for Consolidated and New Application in Human Food, Animal Feed and Nutraceuticals. Int. J. Environ. Res. Public Health 2018, 15, 2436. [CrossRef]

9. Kim, S.M.; Jung, Y.-J.; Kwon, O.-N.; Cha, K.H.; Um, B.-H.; Chung, D.; Pan, C.-H. A Potential Commercial Source of Fucoxanthin Extracted from the Microalga Phaeodactylum tricornutum. Appl. Biochem. Biotechnol. 2012, 166, 1843-1855. [CrossRef]

10. Gügi, B.; Le Costaouec, T.; Burel, C.; Lerouge, P.; Helbert, W.; Bardor, M. Diatom-Specific Oligosaccharide and Polysaccharide Structures Help to Unravel Biosynthetic Capabilities in Diatoms. Mar. Drugs 2015, 13, 5993-6018. [CrossRef]

11. Gilbert-López, B.; Barranco, A.; Herrero, M.; Cifuentes, A.; Ibáñez, E. Development of new green processes for the recovery of bioactives from Phaeodactylum tricornutum. Food Res. Int. 2017, 99, 1056-1065. [CrossRef]

12. Dalmo, R.A.; Bøgwald, J. B-glucans as conductors of immune symphonies. Fish Shellfish Immunol. 2008, 25, 384-396. [CrossRef]

13. Legentil, L.; Paris, F.; Ballet, C.; Trouvelot, S.; Daire, X.; Vetvicka, V.; Ferrières, V. Molecular Interactions of $\beta-(1 \rightarrow 3)-G l u c a n s$ with Their Receptors. Molecules 2015, 20, 9745-9766. [CrossRef] [PubMed]

14. Petit, J.; Bailey, E.C.; Wheeler, R.T.; de Oliveira, C.A.F.; Forlenza, M.; Wiegertjes, G.F. Studies Into $\beta$-Glucan Recognition in Fish Suggests a Key Role for the C-Type Lectin Pathway. Front. Immunol. 2019, 10, 280. [CrossRef]

15. Soltanian, S.; Stuyven, E.; Cox, E.; Sorgeloos, P.; Bossier, P. Beta-glucans as immunostimulant in vertebrates and invertebrates. Crit. Rev. Microbiol. 2009, 35, 109-138. [CrossRef] [PubMed]

16. Brown, G.D.; Herre, J.; Williams, D.L.; Willment, J.A.; Marshall, A.S.; Gordon, S. Dectin-1 mediates the biological effects of beta-glucans. J. Exp. Med. 2003, 197, 1119-1124. [CrossRef] [PubMed]

17. Pietretti, D.; Vera-Jimenez, N.I.; Hoole, D.; Wiegertjes, G.F. Oxidative burst and nitric oxide responses in carp macrophages induced by zymosan, MacroGard ${ }^{\circledR}$ and selective dectin-1 agonists suggest recognition by multiple pattern recognition receptors. Fish Shellfish Immunol. 2013, 35, 847-857. [CrossRef]

18. Ainsworth, A.J. A $\beta$-glucan inhibitable zymosan receptor on channel catfish neutrophils. Vet. Immunol. Immunopathol. 1994, 41, 141-152. [CrossRef] 
19. Esteban, M.A.; Rodriguez, A.; Meseguer, J. Glucan receptor but not mannose receptor is involved in the phagocytosis of Saccharomyces cerevisiae by seabream (Sparus aurata L.) blood leucocytes. Fish Shellfish Immunol. 2004, 16, 447-451. [CrossRef]

20. Kiron, V.; Kulkarni, A.; Dahle, D.; Vasanth, G.; Lokesh, J.; Elvebo, O. Recognition of purified beta 1,3/1,6 glucan and molecular signalling in the intestine of Atlantic salmon. Dev. Comp. Immunol. 2016, 56, 57-66. [CrossRef] [PubMed]

21. El-Boshy, M.E.; El-Ashram, A.M.; AbdelHamid, F.M.; Gadalla, H.A. Immunomodulatory effect of dietary Saccharomyces cerevisiae, $\beta$-glucan and laminaran in mercuric chloride treated Nile tilapia (Oreochromis niloticus) and experimentally infected with Aeromonas hydrophila. Fish Shellfish Immunol. 2010, 28, 802-808. [CrossRef]

22. Chang, C.S.; Huang, S.L.; Chen, S.; Chen, S.N. Innate immune responses and efficacy of using mushroom beta-glucan mixture (MBG) on orange-spotted grouper, Epinephelus coioides, aquaculture. Fish Shellfish Immunol. 2013, 35, 115-125. [CrossRef]

23. Guzmán-Villanueva, L.T.; Tovar-Ramírez, D.; Gisbert, E.; Cordero, H.; Guardiola, F.A.; Cuesta, A.; Meseguer, J.; Ascencio-Valle, F.; Esteban, M.A. Dietary administration of $\beta-1,3 / 1,6$-glucan and probiotic strain Shewanella putrefaciens, single or combined, on gilthead seabream growth, immune responses and gene expression. Fish Shellfish Immunol. 2014, 39, 34-41. [CrossRef] [PubMed]

24. Dawood, M.A.O.; Koshio, S.; Ishikawa, M.; Yokoyama, S. Interaction effects of dietary supplementation of heat-killed Lactobacillus plantarum and $\beta$-glucan on growth performance, digestibility and immune response of juvenile red sea bream, Pagrus major. Fish Shellfish Immunol. 2015, 45, 33-42. [CrossRef] [PubMed]

25. Falco, A.; Frost, P.; Miest, J.; Pionnier, N.; Irnazarow, I.; Hoole, D. Reduced inflammatory response to Aeromonas salmonicida infection in common carp (Cyprinus carpio L.) fed with $\beta$-glucan supplements. Fish Shellfish Immunol. 2012, 32, $1051-1057$. [CrossRef]

26. Falco, A.; Miest, J.J.; Pionnier, N.; Pietretti, D.; Forlenza, M.; Wiegertjes, G.F.; Hoole, D. $\beta$-Glucan-supplemented diets increase poly(I:C)-induced gene expression of $\mathrm{Mx}$, possibly via Tlr3-mediated recognition mechanism in common carp (Cyprinus carpio). Fish Shellfish Immunol. 2014, 36, 494-502. [CrossRef]

27. Dawood, M.A.O.; Metwally, A.E.-S.; El-Sharawy, M.E.; Atta, A.M.; Elbialy, Z.I.; Abdel-Latif, H.M.R.; Paray, B.A. The role of $\beta$-glucan in the growth, intestinal morphometry, and immune-related gene and heat shock protein expressions of Nile tilapia (Oreochromis niloticus) under different stocking densities. Aquaculture 2020, 523, 735205. [CrossRef]

28. Pickering, A.D. Growth and stress in fish production. Aquaculture 1993, 111, 51-63. [CrossRef]

29. Vaseeharan, B.; Thaya, R. Medicinal plant derivatives as immunostimulants: An alternative to chemotherapeutics and antibiotics in aquaculture. Aquac. Int. 2014, 22, 1079-1091. [CrossRef]

30. Zanuzzo, F.S.; Sabioni, R.E.; Montoya, L.N.F.; Favero, G.; Urbinati, E.C. Aloe vera enhances the innate immune response of pacu (Piaractus mesopotamicus) after transport stress and combined heat killed Aeromonas hydrophila infection. Fish Shellfish Immunol. 2017, 65, 198-205. [CrossRef]

31. El-Saadony, M.T.; Alagawany, M.; Patra, A.K.; Kar, I.; Tiwari, R.; Dawood, M.A.O.; Dhama, K.; Abdel-Latif, H.M.R. The functionality of probiotics in aquaculture: An overview. Fish Shellfish Immunol. 2021, 117, 36-52. [CrossRef] [PubMed]

32. Rørstad, G.; Aasjord, P.M.; Robertsen, B. Adjuvant effect of a yeast glucan in vaccines against furunculosis in Atlantic salmon (Salmo salar L.). Fish Shellfish Immunol. 1993, 3, 179-190. [CrossRef]

33. Pilarski, F.; Ferreira de Oliveira, C.A.; Darpossolo de Souza, F.P.B.; Zanuzzo, F.S. Different $\beta$-glucans improve the growth performance and bacterial resistance in Nile tilapia. Fish Shellfish Immunol. 2017, 70, 25-29. [CrossRef] [PubMed]

34. Sakai, M. Current research status of fish immunostimulants. Aquaculture 1999, 172, 63-92. [CrossRef]

35. Couso, N.; Castro, R.; Magariños, B.; Obach, A.; Lamas, J. Effect of oral administration of glucans on the resistance of gilthead seabream to pasteurellosis. Aquaculture 2003, 219, 99-109. [CrossRef]

36. Bricknell, I.; Dalmo, R.A. The use of immunostimulants in fish larval aquaculture. Fish Shellfish Immunol. 2005, 19, 457-472. [CrossRef]

37. Álvarez-Rodríguez, M.; Pereiro, P.; Reyes-López, F.E.; Tort, L.; Figueras, A.; Novoa, B. Analysis of the Long-Lived Responses Induced by Immunostimulants and Their Effects on a Viral Infection in Zebrafish (Danio rerio). Front. Immunol. 2018, 9, 1975. [CrossRef] [PubMed]

38. Petit, J.; Wiegertjes, G.F. Long-lived effects of administering $\beta$-glucans: Indications for trained immunity in fish. Dev. Comp. Immunol. 2016, 64, 93-102. [CrossRef] [PubMed]

39. Bagni, M.; Archetti, L.; Amadori, M.; Marino, G. Effect of long-term oral administration of an immunostimulant diet on innate immunity in sea bass (Dicentrarchus labrax). J. Vet. Med. B Infect. Dis. Vet. Public Health 2000, 47, 745-751. [CrossRef] [PubMed]

40. Paredes, M.; Gonzalez, K.; Figueroa, J.; Montiel-Eulefi, E. Immunomodulatory effect of prolactin on Atlantic salmon (Salmo salar) macrophage function. Fish Physiol. Biochem. 2013, 39, 1215-1221. [CrossRef] [PubMed]

41. Cook, M.T.; Hayball, P.J.; Hutchinson, W.; Nowak, B.F.; Hayball, J.D. Administration of a commercial immunostimulant preparation, EcoActiva ${ }^{\mathrm{TM}}$ as a feed supplement enhances macrophage respiratory burst and the growth rate of snapper (Pagrus auratus, Sparidae (Bloch and Schneider)) in winter. Fish Shellfish Immunol. 2003, 14, 333-345. [CrossRef]

42. Ai, Q.; Mai, K.; Zhang, L.; Tan, B.; Zhang, W.; Xu, W.; Li, H. Effects of dietary $\beta-1,3$ glucan on innate immune response of large yellow croaker, Pseudosciaena crocea. Fish Shellfish Immunol. 2007, 22, 394-402. [CrossRef] [PubMed]

43. Dawood, M.A.O.; Koshio, S.; Ishikawa, M.; Yokoyama, S.; El Basuini, M.F.; Hossain, M.S.; Nhu, T.H.; Moss, A.S.; Dossou, S.; Wei, H. Dietary supplementation of $\beta$-glucan improves growth performance, the innate immune response and stress resistance of red sea bream, Pagrus major. Aquac. Nutr. 2017, 23, 148-159. [CrossRef] 
44. Bagni, M.; Romano, N.; Finoia, M.G.; Abelli, L.; Scapigliati, G.; Tiscar, P.G.; Sarti, M.; Marino, G. Short- and long-term effects of a dietary yeast $\beta$-glucan (Macrogard) and alginic acid (Ergosan) preparation on immune response in sea bass (Dicentrarchus labrax). Fish Shellfish Immunol. 2005, 18, 311-325. [CrossRef] [PubMed]

45. Do Huu, H.; Sang, H.M.; Thanh Thuy, N.T. Dietary $\beta$-glucan improved growth performance, Vibrio counts, haematological parameters and stress resistance of pompano fish, Trachinotus ovatus Linnaeus, 1758. Fish Shellfish Immunol. 2016, 54, 402-410. [CrossRef]

46. Zeng, L.; Wang, Y.-H.; Ai, C.-X.; Zhang, J.-S. Differential effects of $\beta$-glucan on oxidative stress, inflammation and copper transport in two intestinal regions of large yellow croaker Larimichthys crocea under acute copper stress. Ecotoxicol. Environ. Saf. 2018, 165, 78-87. [CrossRef]

47. Carballo, C.; Pinto, P.I.S.; Mateus, A.P.; Berbel, C.; Guerreiro, C.C.; Martinez-Blanch, J.F.; Codoñer, F.M.; Mantecon, L.; Power, D.M.; Manchado, M. Yeast $\beta$-glucans and microalgal extracts modulate the immune response and gut microbiome in Senegalese sole (Solea senegalensis). Fish Shellfish Immunol 2019, 92, 31-39. [CrossRef]

48. Aramli, M.S.; Kamangar, B.; Nazari, R.M. Effects of dietary $\beta$-glucan on the growth and innate immune response of juvenile Persian sturgeon, Acipenser persicus. Fish Shellfish Immunol. 2015, 47, 606-610. [CrossRef] [PubMed]

49. Kühlwein, H.; Merrifield, D.L.; Rawling, M.D.; Foey, A.D.; Davies, S.J. Effects of dietary $\beta-(1,3)(1,6)$-D-glucan supplementation on growth performance, intestinal morphology and haemato-immunological profile of mirror carp (Cyprinus carpio L.). J. Anim. Physiol. Anim. Nutr. 2014, 98, 279-289. [CrossRef]

50. Yamamoto, F.Y.; Sutili, F.J.; Hume, M.; Gatlin, D.M., III. The effect of $\beta$-1,3-glucan derived from Euglena gracilis (Algamune ${ }^{\mathrm{TM}}$ ) on the innate immunological responses of Nile tilapia (Oreochromis niloticus L.). J. Fish Dis. 2018, 41, 1579-1588. [CrossRef]

51. Sahoo, P.K.; Mukherjee, S.C. Effect of dietary $\beta-1,3$ glucan on immune responses and disease resistance of healthy and aflatoxin B1-induced immunocompromised rohu (Labeo rohita Hamilton). Fish Shellfish Immunol. 2001, 11, 683-695. [CrossRef] [PubMed]

52. Pionnier, N.; Falco, A.; Miest, J.; Frost, P.; Irnazarow, I.; Shrive, A.; Hoole, D. Dietary $\beta$-glucan stimulate complement and C-reactive protein acute phase responses in common carp (Cyprinus carpio) during an Aeromonas salmonicida infection. Fish Shellfish Immunol. 2013, 34, 819-831. [CrossRef] [PubMed]

53. Mourente, G.; Díaz-Salvago, E.; Bell, J.G.; Tocher, D.R. Increased activities of hepatic antioxidant defence enzymes in juvenile gilthead sea bream (Sparus aurata L.) fed dietary oxidised oil: Attenuation by dietary vitamin E. Aquaculture 2002, 214, 343-361. [CrossRef]

54. Bobek, P.; Nosálová, V.; Cerná, S. Effect of pleuran (beta-glucan from Pleurotus ostreatus) in diet or drinking fluid on colitis in rats. Food/Nahrung 2001, 45, 360-363. [CrossRef]

55. Kim, Y.-S.; Ke, F.; Zhang, Q.-Y. Effect of $\beta$-glucan on activity of antioxidant enzymes and Mx gene expression in virus infected grass carp. Fish Shellfish Immunol. 2009, 27, 336-340. [CrossRef] [PubMed]

56. Sant, K.E.; Hansen, J.M.; Williams, L.M.; Tran, N.L.; Goldstone, J.V.; Stegeman, J.J.; Hahn, M.E.; Timme-Laragy, A. The role of Nrf1 and Nrf2 in the regulation of glutathione and redox dynamics in the developing zebrafish embryo. Redox Biol. 2017, 13, 207-218. [CrossRef] [PubMed]

57. Wasserman, W.W.; Fahl, W.E. Functional antioxidant responsive elements. Proc. Natl. Acad. Sci. USA 1997, 94, 5361-5366. [CrossRef]

58. Neamat-Allah, A.N.F.; Abd El Hakim, Y.; Mahmoud, E.A. Alleviating effects of $\beta$-glucan in Oreochromis niloticus on growth performance, immune reactions, antioxidant, transcriptomics disorders and resistance to Aeromonas sobria caused by atrazine. Aquac. Res. 2020, 51, 1801-1812. [CrossRef]

59. Carballo, C.; Chronopoulou, E.G.; Letsiou, S.; Maya, C.; Labrou, N.E.; Infante, C.; Power, D.M.; Manchado, M. Antioxidant capacity and immunomodulatory effects of a chrysolaminarin-enriched extract in Senegalese sole. Fish Shellfish Immunol. 2018, 82, 1-8. [CrossRef]

60. Le Costaouëc, T.; Unamunzaga, C.; Mantecon, L.; Helbert, W. New structural insights into the cell-wall polysaccharide of the diatom Phaeodactylum tricornutum. Algal. Res. 2017, 26, 172-179. [CrossRef]

61. Fink, I.R.; Ribeiro, C.M.S.; Forlenza, M.; Taverne-Thiele, A.; Rombout, J.H.W.M.; Savelkoul, H.F.J.; Wiegertjes, G.F. Immunerelevant thrombocytes of common carp undergo parasite-induced nitric oxide-mediated apoptosis. Dev. Comp. Immunol. 2015, 50, 146-154. [CrossRef]

62. Nagasawa, T.; Nakayasu, C.; Rieger, A.M.; Barreda, D.R.; Somamoto, T.; Nakao, M. Phagocytosis by Thrombocytes is a Conserved Innate Immune Mechanism in Lower Vertebrates. Front. Immunol. 2014, 5, 445. [CrossRef] [PubMed]

63. Akramiene, D.; Aleksandraviciene, C.; Grazeliene, G.; Zalinkevicius, R.; Suziedelis, K.; Didziapetriene, J.; Simonsen, U.; Stankevicius, E.; Kevelaitis, E. Potentiating effect of beta-glucans on photodynamic therapy of implanted cancer cells in mice. Tohoku J. Exp. Med. 2010, 220, 299-306. [CrossRef]

64. Lavi, I.; Nimri, L.; Levinson, D.; Peri, I.; Hadar, Y.; Schwartz, B. Glucans from the edible mushroom Pleurotus pulmonarius inhibit colitis-associated colon carcinogenesis in mice. J. Gastroenterol. 2012, 47, 504-518. [CrossRef]

65. Djordjevic, B.; Škugor, S.; Jørgensen, S.M.; Øverland, M.; Mydland, L.T.; Krasnov, A. Modulation of splenic immune responses to bacterial lipopolysaccharide in rainbow trout (Oncorhynchus mykiss) fed lentinan, a beta-glucan from mushroom Lentinula edodes. Fish Shellfish Immunol. 2009, 26, 201-209. [CrossRef] 
66. Goodridge, H.S.; Reyes, C.N.; Becker, C.A.; Katsumoto, T.R.; Ma, J.; Wolf, A.J.; Bose, N.; Chan, A.S.; Magee, A.S.; Danielson, M.E.; et al. Activation of the innate immune receptor Dectin-1 upon formation of a 'phagocytic synapse'. Nature 2011, 472, 471-475. [CrossRef]

67. Qi, C.; Cai, Y.; Gunn, L.; Ding, C.; Li, B.; Kloecker, G.; Qian, K.; Vasilakos, J.; Saijo, S.; Iwakura, Y.; et al. Differential pathways regulating innate and adaptive antitumor immune responses by particulate and soluble yeast-derived $\beta$-glucans. Blood 2011, 117, 6825-6836. [CrossRef] [PubMed]

68. Bose, N.; Chan, A.S.; Guerrero, F.; Maristany, C.; Walsh, R.; Ertelt, K.; Jonas, A.; Gorden, K.; Dudney, C.; Wurst, L.; et al. Binding of Soluble Yeast $\beta$-Glucan to Human Neutrophils and Monocytes is Complement-Dependent. Front. Immunol. 2013, 4, 230. [CrossRef]

69. Kopiasz, Ł.; Dziendzikowska, K.; Gajewska, M.; Wilczak, J.; Harasym, J.; Żyła, E.; Kamola, D.; Oczkowski, M.; Królikowski, T.; Gromadzka-Ostrowska, J. Time-Dependent Indirect Antioxidative Effects of Oat Beta-Glucans on Peripheral Blood Parameters in the Animal Model of Colon Inflammation. Antioxidants 2020, 9, 375. [CrossRef] [PubMed]

70. Żyła, E.; Dziendzikowska, K.; Gajewska, M.; Wilczak, J.; Harasym, J.; Gromadzka-Ostrowska, J. Beneficial Effects of Oat Beta-Glucan Dietary Supplementation in Colitis Depend on Its Molecular Weight. Molecules 2019, 24, 3591. [CrossRef] [PubMed]

71. Sonck, E.; Stuyven, E.; Goddeeris, B.; Cox, E. The effect of $\beta$-glucans on porcine leukocytes. Vet. Immunol. Immunopathol. 2010, 135, 199-207. [CrossRef]

72. Russo, R.; Barsanti, L.; Evangelista, V.; Frassanito, A.M.; Longo, V.; Pucci, L.; Penno, G.; Gualtieri, P. Euglena gracilis paramylon activates human lymphocytes by upregulating pro-inflammatory factors. Food Sci. Nutr. 2017, 5, 205-214. [CrossRef]

73. Derwenskus, F.; Metz, F.; Gille, A.; Schmid-Staiger, U.; Briviba, K.; Schließmann, U.; Hirth, T. Pressurized extraction of unsaturated fatty acids and carotenoids from wet Chlorella vulgaris and Phaeodactylum tricornutum biomass using subcritical liquids. GCB Bioenergy 2019, 11, 335-344. [CrossRef]

74. Mylonas, C.C.; Cardinaletti, G.; Sigelaki, I.; Polzonetti-Magni, A. Comparative efficacy of clove oil and 2-phenoxyethanol as anesthetics in the aquaculture of European sea bass (Dicentrarchus labrax) and gilthead sea bream (Sparus aurata) at different temperatures. Aquaculture 2005, 246, 467-481. [CrossRef]

75. Afonso, A.; Ellis, A.E.; Silva, M.T. The leucocyte population of the unstimulated peritoneal cavity of rainbow trout (Oncorhynchus mykiss). Fish Shellfish Immunol. 1997, 7, 335-348. [CrossRef]

76. Machado, M.; Azeredo, R.; Díaz-Rosales, P.; Afonso, A.; Peres, H.; Oliva-Teles, A.; Costas, B. Dietary tryptophan and methionine as modulators of European seabass (Dicentrarchus labrax) immune status and inflammatory response. Fish Shellfish Immunol. 2015, 42, 353-362. [CrossRef]

77. Ellis, A.E.; Cavaco, A.; Petrie, A.; Lockhart, K.; Snow, M.; Collet, B. Histology, immunocytochemistry and qRT-PCR analysis of Atlantic salmon, Salmo salar L., post-smolts following infection with infectious pancreatic necrosis virus (IPNV). J. Fish Dis. 2010, 33, 803-818. [CrossRef] [PubMed]

78. Bird, R.P.; Draper, H.H. Comparative studies on different methods of malonaldehyde determination. Methods Enzymol. 1984, 105, 299-305. [PubMed]

79. Claiborne, A. Catalase activity. In Handbook of Methods for Oxygen Radical Research; Greenwald, R.A., Ed.; CRC Press Inc.: Boca Raton, FL, USA, 1984; pp. 283-284.

80. Flohé, L.; Otting, F. Superoxide dismutase assays. Methods Enzymol. 1984, 105, 93-104.

81. Lima, I.; Moreira, S.M.; Osten, J.R.-V.; Soares, A.M.V.M.; Guilhermino, L. Biochemical responses of the marine mussel Mytilus galloprovincialis to petrochemical environmental contamination along the North-western coast of Portugal. Chemosphere 2007, 66, 1230-1242. [CrossRef] [PubMed]

82. Tietze, F. Enzymic method for quantitative determination of nanogram amounts of total and oxidized glutathione: Applications to mammalian blood and other tissues. Anal. Biochem. 1969, 27, 502-522. [CrossRef]

83. Baker, M.A.; Cerniglia, G.J.; Zaman, A. Microtiter plate assay for the measurement of glutathione and glutathione disulfide in large numbers of biological samples. Anal. Biochem. 1990, 190, 360-365. [CrossRef]

84. Livak, K.J.; Schmittgen, T.D. Analysis of relative gene expression data using real-time quantitative PCR and the 2(-Delta Delta C(T)) Method. Methods 2001, 25, 402-408. [CrossRef]

85. Wold, S.; Sjöström, M.; Eriksson, L. PLS-regression: A basic tool of chemometrics. Chemometr. Intell. Lab. Syst. 2001, 58, 109-130. [CrossRef]

86. Li, H.; Ma, M.-L.; Luo, S.; Zhang, R.-M.; Han, P.; Hu, W. Metabolic responses to ethanol in Saccharomyces cerevisiae using a gas chromatography tandem mass spectrometry-based metabolomics approach. Int. J. Biochem. Cell Biol. 2012, 44, 1087-1096. [CrossRef]

87. Kieffer, D.A.; Piccolo, B.D.; Vaziri, N.D.; Liu, S.; Lau, W.L.; Khazaeli, M.; Nazertehrani, S.; Moore, M.E.; Marco, M.L.; Martin, R.J.; et al. Resistant starch alters gut microbiome and metabolomic profiles concurrent with amelioration of chronic kidney disease in rats. Am. J. Physiol.-Renal Physiol. 2016, 310, F857-F871. [CrossRef] [PubMed] 